\title{
Modifying the Subunit Composition of TASK Channels Alters the Modulation of a Leak Conductance in Cerebellar Granule Neurons
}

\author{
M. Isabel Aller, ${ }^{1}$ Emma L. Veale, ${ }^{3}$ Anni-Maija Linden, ${ }^{4}$ Cristina Sandu, ${ }^{1}$ Markus Schwaninger, ${ }^{2}$ Louisa J. Evans, ${ }^{3}$ \\ Esa R. Korpi, ${ }^{4}$ Alistair Mathie, ${ }^{3}$ William Wisden, ${ }^{1}$ and Stephen G. Brickley ${ }^{3}$ \\ Departments of ${ }^{1}$ Clinical Neurobiology and ${ }^{2}$ Neurology, University of Heidelberg, 69120 Heidelberg, Germany, ${ }^{3}$ Division of Cell and Molecular Biology, \\ Imperial College London, London SW7 2AZ, United Kingdom, and ${ }^{4}$ Institute of Biomedicine, Pharmacology, FI-00014 University of Helsinki, Helsinki, \\ Finland
}

Two-pore domain potassium $\left(\mathrm{K}_{2 \mathrm{P}}\right)$ channel expression is believed to underlie the developmental emergence of a potassium leak conductance $\left[I_{\mathrm{K}(\mathrm{SO})}\right]$ in cerebellar granule neurons (CGNs), suggesting that $\mathrm{K}_{2 \mathrm{P}}$ function is an important determinant of the input conductance and resting membrane potential. To investigate the role that different $\mathrm{K}_{2 \mathrm{P}}$ channels may play in the regulation of CGN excitability, we generated a mouse lacking TASK-1, a $\mathrm{K}_{2 \mathrm{P}}$ channel known to have high expression levels in CGNs. In situ hybridization and real-time PCR studies in wild-type and TASK-1 knock-outs (KOs) demonstrated that the expression of other $\mathrm{K}_{2 \mathrm{P}}$ channels was unaltered in CGNs. TASK-1 knock-out mice were healthy and bred normally but exhibited compromised motor performance consistent with altered cerebellar function. Whole-cell recordings from adult cerebellar slice preparations revealed that the resting excitability of mature CGNs was no different in TASK-1 KO and littermate controls. However, the modulation of $I_{\mathrm{K}(\mathrm{so})}$ by extracellular $\mathrm{Zn}^{2+}$, ruthenium red, and $\mathrm{H}^{+}$was altered. The $I_{\mathrm{K}(\mathrm{SO})}$ recorded from TASK-1 knock-out CGNs was no longer sensitive to alkalization and was blocked by $\mathrm{Zn}^{2+}$ and ruthenium red. These results suggest that a TASK-1-containing channel population has been replaced by a homodimeric TASK-3 population in the TASK-1 knock-out. These data directly demonstrate that TASK-1 channels contribute to the properties of $I_{\mathrm{K}(\mathrm{SO})}$ in adult CGNs. However, TASK channel subunit composition does not alter the resting excitability of CGNs but does influence sensitivity to endogenous modulators such as $\mathrm{Zn}^{2+}$ and $\mathrm{H}^{+}$.

Key words: potassium channels; cerebellum; motor control; patch-clamp; knock-out mice; excitability

\section{Introduction}

Two-pore potassium channels $\left(\mathrm{K}_{2 \mathrm{P}}\right)$ (Gutman et al., 2003) set the resting membrane potential of many neuronal types by generating a potassium leak conductance (North, 2000; Goldstein et al., 2001; Patel and Honoré, 2001; Bayliss et al., 2003; Lesage, 2003). Cerebellar granule neurons (CGNs) exhibit a potassium leak conductance $\left[I_{\mathrm{K}(\mathrm{SO})}\right]$ (Watkins and Mathie, 1996) that explains their relatively hyperpolarized resting membrane potential (ap-

\footnotetext{
Received May 4, 2005; revised Sept. 19, 2005; accepted 0ct. 20, 2005.

This work was supported by the Wellcome Trust (S.B.), the Medical Research Council (MRC) (A.M.), the German Research Council Deutsche Forschungsgemeinschaft (DFG) WI 1951/1-2 (W.W.), DFG Sonderforschungsbereich 488 "Molecular and cellular basis of neural development" (W.W.), the Volkswagen Stiftung I/78 554 (W.W.), the Fonds der Chemischen Industrie (W.W.), and the Academy of Finland (E.R.K.). We thank V. Revilla (MRC, Cambridge, UK) for initial help in obtaining and characterizing the TASK1 BAC clones, H. Monyer (Heidelberg, Germany) for discussion and support, F. Zimmermann (Zentrale Tierlabor, Heidelberg, Germany) for blastocyst injections, R. Bruzzone (Pasteur Institute, Paris, France) for drawing our attention to the $\mathrm{pCS} 2+$ vector, K. J. Mitchell and W. C. Skarnes (Wellcome Trust Sanger Institute, Hinxton, UK) and R. Warth (Regensburg, Germany) for supply of TASK-2 knock-out mice, and I. Preugschat-Gumprecht (Heidelberg, Germany) for help with mouse genotyping.

Correspondence should be addressed to either of the following: Stephen G. Brickley, Division of Cell and Molecular Biology, Huxley Building, Room 741, Imperial College London, London, SW7 2AZ, UK, E-mail: s.brickley@imperial.ac.uk; or William Wisden at his present address: Institute of Medical Sciences, University of Aberdeen, Foresterhill, Aberdeen AB25 2ZD, UK, E-mail:w.wisden@abdn.ac.uk.

DOI:10.1523/JNEUROSCI.3153-05.2005

Copyright $\odot 2005$ Society for Neuroscience $\quad$ 0270-6474/05/2511455-13\$15.00/0
}

proximately $-80 \mathrm{mV}$ ). However, it is currently not clear what role specific $\mathrm{K}_{2 \mathrm{P}}$ channels play in the generation of these potassium leak conductances in the adult brain and what impact the modulation of $I_{\mathrm{K}(\mathrm{SO})}$ properties will have on cerebellar function.

Although the developmental emergence of $I_{\mathrm{K}(\mathrm{SO})}$ correlates with $\mathrm{K}_{2 \mathrm{P}}$ channel expression (Millar et al., 2000; Brickley et al., 2001; Lauritzen et al., 2003), identifying which $\mathrm{K}_{2 \mathrm{P}}$ channels give rise to this leak conductance is not simple (Mathie et al., 2003). For example, five $\mathrm{K}_{2 \mathrm{P}}$ channel genes, TWIK-1, TASK-1, TASK-3, the TREK-2c splice variant, and THIK-2 are expressed at high levels in CGNs (Duprat et al., 1997; Brickley et al., 2001; Karschin et al., 2001; Rajan et al., 2001; Talley et al., 2001; Vega-Saenz de Miera et al., 2001; Gu et al., 2002). All of these $\mathrm{K}_{2 \mathrm{P}}$ types share sufficiently similar biophysical properties to explain $I_{\mathrm{K}(\mathrm{SO})}$, but the absence of selective pharmacological agents has hindered the identification of the $\mathrm{K}_{2 \mathrm{P}}$ channels responsible. Thus, gene knockouts (KOs) and expression of dominant-negative constructs offer a useful strategy for the identification of $\mathrm{K}_{2 \mathrm{P}}$ subunit composition in vivo (Lauritzen et al., 2003; Berg et al., 2004; Heurteaux et al., 2004; Warth et al., 2004).

A pH-sensitive component of $I_{\mathrm{K}(\mathrm{SO})}$ has been described in both cultured CGNs (Watkins and Mathie, 1996; Millar et al., 2000; Han et al., 2002; Lauritzen et al., 2003) and cells in the acute 
slice preparation (Millar et al., 2000; Brickley et al., 2001; Takayasu et al., 2003). Both TASK-1 and TASK-3, when recombinantly expressed, assemble as dimers to form a $\mathrm{pH}$-sensitive potassium leak conductance (Duprat et al., 1997; Kim et al., 1998; Leonoudakis et al., 1998; Lopes et al., 2000). In situ hybridization studies (Duprat et al., 1997; Talley et al., 2000, 2001; Brickley et al., 2001; Karschin et al., 2001; Medhurst et al., 2001) indicate that TASK-1 gene expression is highest in CGNs, whereas the TASK-3 gene is more evenly expressed throughout the CNS, including CGNs (see Figs. 1, 2). Consistent with biochemical studies of coexpressed recombinant TASK proteins (Czirjak and Enyedi, 2002; Berg et al., 2004), TASK-1and TASK-3-containing channels could be heterodimers in cultured granule cells (Kang et al., 2004). However, the possible contribution of TASK-1/TASK-3 channels to $I_{\mathrm{K}(\mathrm{SO})}$ in adult CGNs has yet to be established. We generated a TASK-1 KO mouse strain to explore how TASK-1 channels contribute to $I_{\mathrm{K}(\mathrm{SO})}$ in CGNs in both culture and the adult slice preparation.

\section{Materials and Methods}

\section{Generation of the TASK-1 KO line}

Exon 1 of the TASK-1 gene $\left(\mathrm{K}_{2 \mathrm{p}} 3.1\right)$ (Duprat et al., 1997; Kim et al., 1998; Leonoudakis et al., 1998), encoding the first transmembrane domain through to the beginning of the first P1 loop (Lopes et al., 2000), was disrupted by homologous recombination in mouse embryonic stem cells. The genomic region on mouse chromosome 5B2 containing the 35.4 KbTASK-1 gene (gene reference number ENSMUSG00000049265; (http://www.ensembl.org/ Mus_musculus/geneview?gene = ENSMUSG00000049265) was obtained on a bacterial artificial chromosome (BAC) by screening a mouse 129 BAC library (BAC Mouse ES release I, BAC 4921; Genome Systems, St. Louis, MO) with a TASK1 cDNA probe generated by reverse transcription (RT)-PCR from mouse brain mRNA using primers 5'-AAG GAC CAG GCG CTG CAG AC-3' (nucleotides 554-573; sense) and 5'-TGC ACC GTG CCA AGA GGG-3' (nucleotides 1343-1326; antisense) To construct the targeting vector, a $9.0 \mathrm{~kb} S p h \mathrm{I}$ fragment of the TASK-1 gene, containing the first coding exon (Fig. 1A, black box) was subcloned into a pBluescript (Stratagene, La Jolla, CA) vector that contained a modified polylinker, with the EcoRV site converted to SphI. This plasmid was then digested with EcoRI and religated, giving the targeting vector backbone, a $7.3 \mathrm{~Kb} S p h \mathrm{I}-$ EcoRI fragment (Fig. $1 \mathrm{~A}$ ). Into the unique $S f o \mathrm{I}$ site in exon 1 we ligated BamHI adaptors, allowing insertion into this position of the TAG $\mathrm{T}_{3}$ RESlacZpAneopA cassette (gift from A. J. H. Smith, Edinburgh, UK) (Jones et al., 1997) in the same transcriptional orientation as the TASK-1 gene, so giving the final targeting vector (Fig. $1 \mathrm{~A}$ ). This cassette contains stop codons (TAG) in all three reading frames, followed by an internal ribosome entry site (IRES) linked to a $\beta$-galacto-

\section{TASK-1 mRNA}
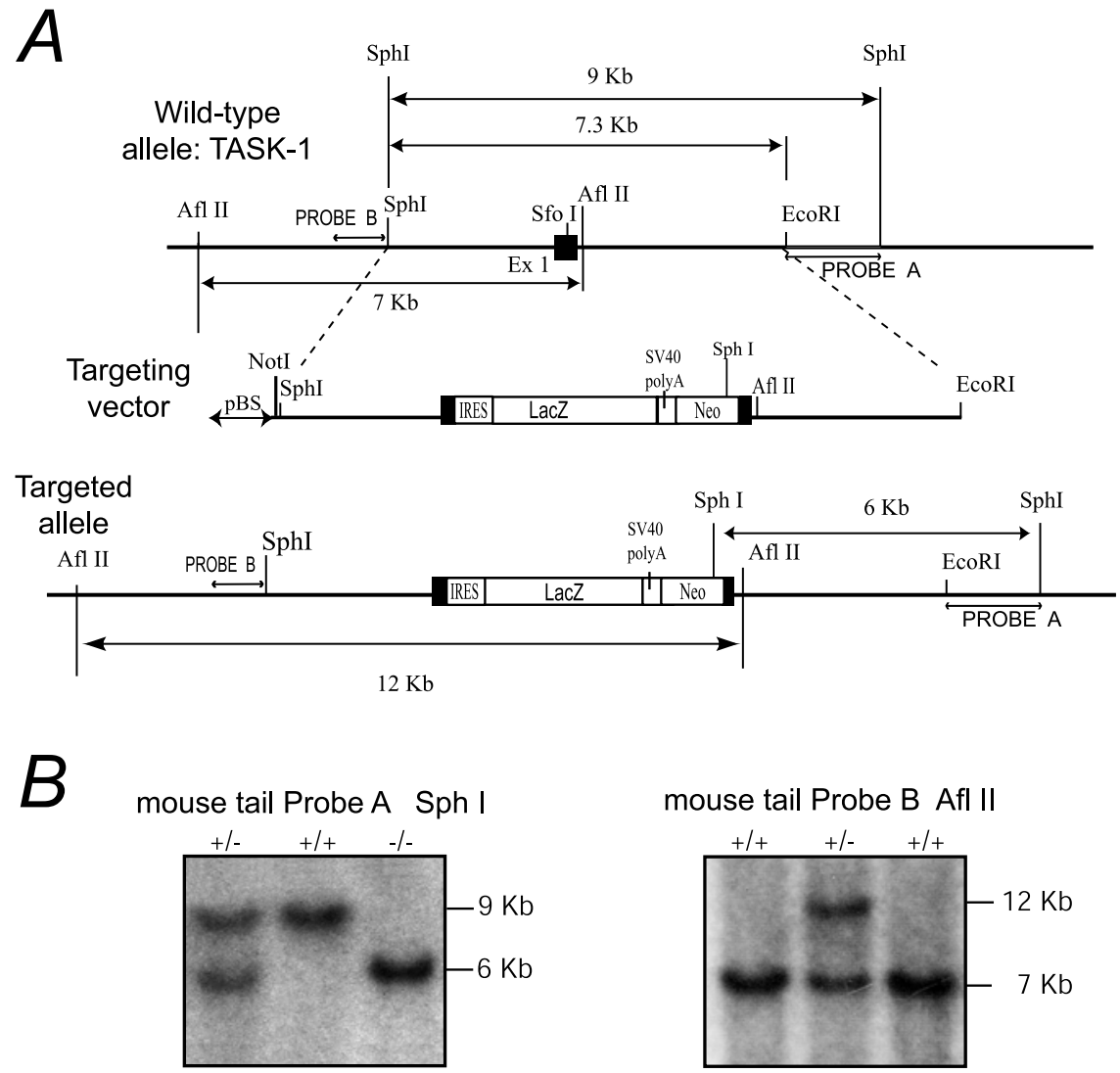

\section{Wild-type (+/+) TASK-1 KO (+/-) TASK-1 KO (-/-)}

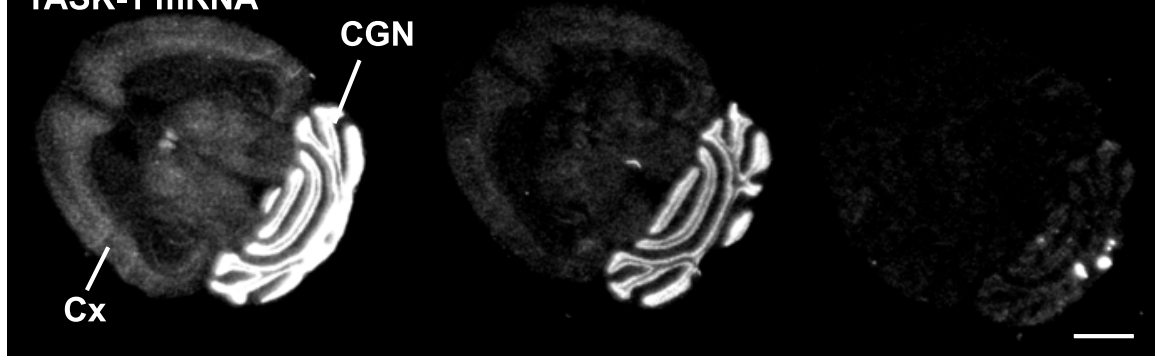

Figure 1. TASK-1 gene targeting to generate a knock-out allele. $\boldsymbol{A}$, Homologous recombination strategy for exon 1 (Ex 1 ) of the mouse TASK-1 gene showing the structure of the native gene (top), the linearized targeting vector (middle), and the targeted allele (bottom). Exon 1 is marked as a filled box. pBS, pBluescript; SV40 polyA, Simian virus 40 polyadenylation; Neo, neomycin. $\boldsymbol{B}$, Southern blots confirming germ-line transmission of the targeted TASK-1 allele. After Sphl digestion and hybridizing with Probe $A$, which flanks the $3^{\prime}$ end of the targeting vector, wild-type bands are $9 \mathrm{~kb}$, but a heterozygote mouse $(+/-)$ gives an additional $6 \mathrm{~kb}$ band; homozygous mice ( $-/-$ ) have only the $6 \mathrm{~kb}$ band. When tail DNA is digested with AfIll, and the blot is hybridized with a $5^{\prime}$ flanking probe (Probe B), a $12 \mathrm{~kb}$ band from the targeted allele is found (+/-), whereas the wild-type gene gives a $7 \mathrm{~kb}$ band. $C$, In situ hybridization showing absence of TASK-1 mRNA in adult TASK-1 knock-out mouse brains. In situ hybridization autoradiographs (x-ray film) with a ${ }^{35}$ S-labeled antisense oligonucleotide complimentary to the nucleotides encoding amino acids 1-15 (i.e., $N$ terminus) of TASK-1. In the wild-type $(+/+)$, the signal is highest in CGNs but is also present in cortex (Cx), thalamus, and inferior colliculus; in heterozygotes $(+/-)$, the signal is partially reduced, and in the knock-out $(-/-)$, no specific signal remains. Scale bar, $2 \mathrm{~mm}$.

sidase (lacZ) reading frame and Simian virus 40 polyadenylation sequences, and then a neomycin resistance gene under independent transcriptional control (Fig. 1A).

The cassette was intended to be placed 21 amino acids downstream of the initiator methionine codon, following the peptide sequence TYLLV (Fig. 1A) (Duprat et al., 1997; Leonoudakis et al., 1998). However, on sequencing the targeting vector, we found that the TAG $\mathrm{IRESlacZ}_{3}$ cas- 
sette actually started 15 nucleotides upstream of the initiator ATG codon of the TASK-1 gene; we had thus made a 72 bp deletion of exon 1 , removing entirely the region encoding the first 21 amino acids. Nevertheless, because the IRES was still positioned in the presumed transcribed and $5^{\prime}$ untranslated region (UTR), we reasoned that the IRES should still support translation of lacZ. The targeting vector was linearized with Not I and electroporated into mouse embryonic stem cells (strain 129/Sv, RI). We identified three targeted colonies of 490 screened by Southern blotting; colony genomic DNA was digested with $S p h$ I and hybridized with probe A flanking the $3^{\prime}$ end of the targeting vector (Fig. $1 A$ ), giving a $9 \mathrm{~kb}$ wild-type band or $6 \mathrm{~kb}$ for the targeted allele (Fig. $1 B$ ). Recombination was confirmed by digesting genomic DNA with AflII and hybridizing with probe $\mathrm{B}$, giving a $7 \mathrm{~kb}$ band for the wild-type and $12 \mathrm{~kb}$ band for the targeted allele (Fig. 1C). A targeted stem cell colony was injected into mouse blastocysts; the resulting chimeras were bred with C57BL/6 wildtype mice, and germ-line transmission of the targeted TASK-1 allele was confirmed with probes A and B using mouse tail DNA (Fig. $1 B, C$ ). All subsequent generations have been maintained on a C57BL/ 6 background and genotyped using probe $\mathrm{A}$ and $\mathrm{Sph} \mathrm{I}$ digestion. No lacZ expression could be detected in the TASK-1 KO $(-/-)$ brains or hearts (see Fig. 2, and data not shown). Although TASK-1 expression was clearly absent in the TASK-1 KO strain, two commercially available antibodies, reported to selectively label TASK-1 protein [Alomone Labs (Jerusalem, Israel) and Sigma (Poole, UK)], gave staining patterns by immunocytochemistry and Western blots in the TASK-1 KO identical to those observed in the wild type (data not shown).

\section{In situ hybridization}

In situ hybridization with ${ }^{35}$ S-labeled oligonucleotide probes was as described previously (Wisden and Morris, 1994). As a control for specificity, two independent oligonucleotides for each gene were hybridized in parallel. Probes within each pair gave identical results. Three wild-type littermate and three TASK-1 KO brains were used for each probe pair. The oligonucleotide sequences used were as follows: mTASK-1a, 5' -GGT GCA CAC GAT GAG AGC CAA CGT GCG CAC ATT CTG CCG CTT CAT CG-3'; mTASK-1b, 5' -TCA CAC CGA GCT CCT GCG CTT CAT GAG GCC GCG GAA GGC AGC CAG-3'; mTASK-2a, 5'-GTA GAA TAT GAT GGC CGA GGT GAG TAA AGG ACC CCG GTC CAC CAT3'; mTASK-2b, 5' -CGT GCC CCT GGG GTT ATC TGC CTT GTT GTA TTC GTT CAT CAG CTG-3'; rTASK-3a, 5'-GAT GGA CTT GCG ACG GAT GTG CAG CCT GTG GTT TTC CCC GCA GGT GTG CAT-3'; rTASK-3b, 5'-GTA CTT GCC TCT GAG GCG GAC CTC TTC TGC TTT AAG TTT CTC CTC-3'; TWIK-1a, 5' -CTC CAC CAG GCG CAC GCA CGA GCT GCC GGC CAG GGA CTG CAG CAT-3'; TWIK-1b, 5'-GTG GTC TGC AGA GCC ATC CTC ATA GGG TGG GGA CTG GGA GGC CAC; TWIK-2a, 5' -CAT AAG CAG GAG CAG GTA TCG GGC CCA TGG TTT CAG ACT CCC CAT-3'; TWIK-2b, 5' -AGG TCC CCC AAC ACG ATC GAG CTG ACT TCC TGT CGC CTG ACT GGG3'; TREK-1a, 5' -GTT CTG AGC AGC AGA CTT GGG ATC CAG CAA GTC AGG GGC CGC CAT-3'; TREK-1b, 5' -CTT CAT GTT CTC AAT GAC AGC TAT GTC CTC ACC AGC ACA GTG TGG-3'; TREK-2c(1), 5'-ATC CCA GTT CAC CTG CTT TCT TGG CGT CTC GAT TGG AAA TTT CAT-3'; TREK-2c(2), 5' -ATG GCT CCC GTG GAT ACC AGG CAC GAA GAT ATG AGT GCA GAC AAA [the TREK-2 probes detect the TREK-2c and pan-TREK2 expression (Gu et al., 2002)]; THIK-2a, 5'-TAT GGT CGA CAC CAC GGT GCC CAC GAA GTA GAA CCG AGG TCC CTT-3'; THIK-2b, CTC GGA CAG CTG CTT CTG CAG CAG CGC CAG CGA CAC CTT GTT GGA-3'; THIK-1a, 5'-GTC GTC CAT CAG TGT CAC GTT CCA TCA CCC CGT CTG TCT CTA T-3'; THIK-1b, $5^{\prime}$-GCT ACT TCT GGT TCC TAC CTA TCT CCA CTG GTC TCT GCC AAC CTG-3'; TRAAKa, 5' -AAG CAG CAC CAG TGC CAG CAG AGC CAG GAG TGT GGT GCT GCG CAT-3'; and TRAAKb, 5'-CAC CGG CAC GGC CTT GTC TCG GAG TCG CCC AGG ACC CCG GGG TCT-3' (the two TRAAK probes were hybridized together because the individual probe signals were too weak).

Images were generated from a 4 week exposure to Biomax MR (Eastman Kodak, Rochester, NY) x-ray film (except for TRAAK, which required 12 weeks exposure to the same film). To assess nonspecific label- ing of the sections, each labeled oligonucleotide was hybridized to brain sections with a 100 -fold excess of unlabeled oligonucleotide.

\section{Real-time quantitative RT-PCR}

Using Ultraspec RNA reagents (Biotecx Laboratories, Houston, TX), total RNA from cerebellum and forebrain was isolated from adult TASK-1 $\mathrm{KO}(-/-)$, wild-type littermate, and $\mathrm{GABA}_{\mathrm{A}}$ receptor $\alpha 6$ subunit $-/-$ mice $(\Delta \alpha 6$ lacZ) (Jones et al., 1997). RNAs were treated for 15 min with DNase I (Qiagen, Valencia, CA) and cleaned with an RNeasy Mini kit (Qiagen). Reverse transcription was performed with $5 \mu \mathrm{g}$ of total RNA using a SuperScript Double-Stranded cDNA Synthesis kit (Invitrogen, Paisley, UK). Real-time PCR with SYBR green was performed with the following protocol: $10 \mathrm{~min}$ at $95^{\circ} \mathrm{C}, 15 \mathrm{~s}$ at $95^{\circ} \mathrm{C}$, and $1 \mathrm{~min}$ at $60^{\circ} \mathrm{C}(40$ cycles) using a SYBR green PCR kit (PE Applied Biosystems, Weiterstadt, Germany) and a Gene Amp 5700 sequence detector (PE Applied Biosystems). A linear concentration-amplification curve was established by diluting pooled samples. Quantified results for individual cDNAs were normalized to cyclophilin. The purity of the amplified products was checked by the dissociation curve. Each experiment was performed in triplicate, and the sequences used were as follows: TASK-1 forward, $5^{\prime}$ CGGCTTCCGCAACGTCTAT-3'; TASK-1 reverse, 5'-TTGTACCAGAGGCACGAGCA-3'; TASK-2 forward, $5^{\prime}$-ACAAGATCCTACAGGTGGTGTCTG-3'; TASK-2 reverse, 5'-GAAAGTCTGGTTCCCGGTGAT-3'; TASK-3 forward: 5'-GACGTGCTGAGGAACACCTACTT-3'; TASK-3 reverse, 5'-GTGTGCATTCCAGGAGGGA-3'; THIK-2 forward, GGGACTTCCCTGGAGCCTTC-3'; THIK-2 reverse, GTCATGCCGAAACCTATGGTCG-3'; TREK-1 forward, 5' CTGGTGGTCGTCCTC-3'; TREK-1 reverse, 5'-GCTGCTCCAATGCCTTGAAC-3'; TREK-2 forward, 5'-CCGGAATTACTCTCTGGATGAAGA-3'; TREK-2 reverse, 5'-CATGGCTGTGCTGGAGTTGT-3'; TRAAK- forward, $5^{\prime}$-CCCCAGTGAGAATCTGGCC-3'; TRAAK- reverse, 5'-GGGCACAGCCACGCTC-3'; TWIK-1 forward, 5-TGTCCTTCTCCTCCGTCACTG-3'; TWIK-1 reverse, 5-AGGCCACAAAAGGCTCACTTT-3'; TRESK forward, 5'-CGGTTCCAGGCTCTCCTTTGC-3'; ${ }^{\prime}$ TRESK reverse, $5^{\prime}$-TTTGCTGTCAGGCTGCTTCCG-3'; GABA $\delta$ forward, $5^{\prime}$-CTCCATGGGTCCCAAAATGGG-3'; GABA $\delta$ reverse, 5' -GCAGGCTCGTCTTTAGAGCAA-3'; GABA $\alpha 6$ forward, 5' AAGCGTCTGAATCCCTGGAA-3'; GABA $\alpha 6$ reverse: $5^{\prime}$-TACTTGGAGTCAGAATGCACAACA-3'; cyclophilin forward, $5^{\prime}$-AGGTCCTGGCATCTTGTCCAT-3'; and cyclophilin reverse, 5'-GAACCGTTTGTGTTTGGTCCA-3'.

\section{Recombinant expression}

Isolation of mouse TASK-1 and TASK-3 full-length cDNAs. Mouse brain cDNA was prepared as for the real-time PCR assay (see above section). PCR primers were designed from the mouse TASK-1 cDNA sequence (GenBank sequence number AF065162) (Kim et al., 1998): forward primer, 5' -ggatccATGAAGCGGCAGAATGTG-3' (lowercase letters indicate BamHI site); and reverse primer, 5'-gtcgacTCACACCGAGCTCCTGCG-3' (lowercase letters indicate Sall site) [25 cycles at $94^{\circ} \mathrm{C}$ for $45 \mathrm{~s}, 55^{\circ} \mathrm{C}$ for $45 \mathrm{~s}$, and $72^{\circ} \mathrm{C}$ for 1 min $20 \mathrm{~s}$; Pfu turbo DNA polymerase (Stratagene), $1 \mu \mathrm{g}$ of brain cDNA]. The PCR fragment was subcloned into the PCR-Script vector (PCR-Script Amp Cloning kit; Stratagene), excised with BamHI and SalI, and further subcloned into a BamHI-XhoI cut pCS2 + cytomegalovirus-based expression vector (for details on this plasmid, see http://sitemaker.umich.edu/dlturner.vectors). The coding region of TASK-3 was amplified with the same conditions as for TASK-1 using PCR primers designed from the mouse predicted cDNA sequence (www.ensembl.org/Mus_musculus/geneview?gene $=$ ENSMUSG00000036760): forward primer, 5' -tccttcttcgcggccATGAAGCGG-3'; and reverse primer, $5^{\prime}$-acttccctcccacacTTAGATGGACTT- $3^{\prime}$ (25 cycles at $94^{\circ} \mathrm{C}$ for $45 \mathrm{~s}, 54^{\circ} \mathrm{C}$ for $45 \mathrm{~s}, 72^{\circ} \mathrm{C}$ for $1 \mathrm{~min} 20 \mathrm{~s}$ ). Lowercase letters indicate the $5^{\prime}$ UTR and $3^{\prime}$ UTR sequences in the forward and reverse primers, respectively. The PCR fragment was subcloned into PCR-Script, excised with Bam HI and NotI, treated with Klenow, and subcloned into StuI-linearized pCS2 + . The final constructs were checked by complete sequencing.

Culture and transfection of cells. Modified HEK-293 cells (tsA-201) were maintained in $5 \% \mathrm{CO}_{2}$ in a humidified incubator at $37^{\circ} \mathrm{C}$ in growth 
media [89\% DMEM, 10\% heat-inactivated fetal bovine serum, $1 \%$ penicillin $(10,000 \mathrm{U} / \mathrm{ml})$, and streptomycin $(10 \mathrm{mg} / \mathrm{ml})]$. When the tsA-201 cells were $80 \%$ confluent, they were split and plated for transfection onto glass coverslips coated with poly-D-lysine $(1 \mathrm{mg} / \mathrm{ml})$ to ensure good cell adhesion. The tsA-201 cells were transiently transfected using the calcium phosphate method. A total of $1 \mu \mathrm{g}$ of cDNA expression vector encoding a mouse or human TASK-1 or TASK-3 subunit was added to each $15 \mathrm{~mm}$ well, and $1 \mu \mathrm{g}$ of a plasmid encoding the cDNA of green fluorescent protein was included to identify cells expressing $\mathrm{K}_{2 \mathrm{P}}$ channels. After a $24 \mathrm{~h}$ incubation period at $3 \% \mathrm{CO}_{2}$, the cells were rinsed with saline and fresh growth medium was added to the wells. The cells were incubated at $37^{\circ} \mathrm{C}$ with $5 \% \mathrm{CO}_{2}$ for $12-60 \mathrm{~h}$ before electrophysiological measurements were made. Human TASK-1 and TASK-3 (Meadows and Randall, 2001) $\mathrm{K}_{2 \mathrm{P}}$ channel clones in the pcDNA 3.1 vector were kindly provided by Dr. Helen Meadows at GlaxoSmithKline (Middlesex, UK).

\section{CGN cultures}

For each preparation, two postnatal day 7 (P7) mice were killed by cervical dislocation, and the cerebella were removed and placed in ice-cold DMEM (Invitrogen). The cerebella were chopped into $<1 \mathrm{~mm}^{3}$ pieces and incubated at $37^{\circ} \mathrm{C}$ in a trypsin-containing solution $(0.25 \mathrm{mg} / \mathrm{ml})$ for $30 \mathrm{~min}$ before being spun at $1200 \mathrm{rpm}$ for $5 \mathrm{~min}$. The cells were then triturated, spun again, and finally plated on $10 \mu \mathrm{g} / \mathrm{ml}$ poly-D-lysinecoated coverslips at an approximate density of $3 \times 10^{6}$ cells $/ \mathrm{ml}$. Cells were cultured in DMEM (Invitrogen) supplemented with $10 \%$ fetal bovine serum (Invitrogen) with a final $\mathrm{K}^{+}$concentration of $25 \mathrm{~mm}$. After $48 \mathrm{~h}, 10 \mu \mathrm{M}$ cytosine arabinoside (Sigma) was included in the medium to reduce non-neuronal proliferation. The cells were cultured in a humidified $5 \% \mathrm{CO}_{2}$ atmosphere at $37^{\circ} \mathrm{C}$ before being used for experiments at 2 , 7 , and $14 \mathrm{~d}$ in culture.

\section{Acute slice preparations}

A total of 15 wild-type mice (P75 \pm P15) and 17 TASK-1 KO mice (P97 \pm P20) were used for this aspect of the study. The mice were killed by cervical dislocation, and the brains were rapidly removed and placed into an ice-cold artificial CSF. A sucrose replacement technique, adapted from Mann-Metzer and Yarom (1999), was used for preparation of parasagittal cerebellar slices ( $250 \mu \mathrm{m}$ thick). The brain was rapidly dissected and submerged in cold slicing solution $\left(\sim 4^{\circ} \mathrm{C}\right)$ containing the following (in mM): $85 \mathrm{NaCl}, 2.5 \mathrm{KCl}, 1 \mathrm{CaCl}_{2}, 4 \mathrm{MgCl}_{2}, 25 \mathrm{NaHCO}_{3}, 1.25$ $\mathrm{NaH}_{2} \mathrm{PO}_{4}, 75$ sucrose, and 25 glucose. All extracellular solutions were bubbled with $95 \% \mathrm{O}_{2}$ and $5 \% \mathrm{CO}_{2}$, $\mathrm{pH}$ 7.4. After cutting on a movingblade microtome (Dosaka, Kyoto, Japan), slices were maintained in sucrose solution at $34^{\circ} \mathrm{C}$ for an additional $30 \mathrm{~min}$ before the slicing solution was gradually replaced with a solution containing the following (in $\mathrm{mM}$ ): $125 \mathrm{NaCl}, 2.5 \mathrm{KCl}, 1 \mathrm{CaCl}_{2}, 4 \mathrm{MgCl}_{2}, 26 \mathrm{NaHCO}_{3}, 1.25 \mathrm{NaH}_{2} \mathrm{PO}_{4}$, and 25 glucose. Slices were then transferred to a recording chamber and constantly perfused $(2 \mathrm{ml} / \mathrm{min})$ with standard recording solution that contained the following (in mM): $125 \mathrm{NaCl}, 2.5 \mathrm{KCl}, 1 \mathrm{CaCl}_{2}, 2 \mathrm{MgCl}_{2}, 26$ $\mathrm{NaHCO}_{3}, 1.25 \mathrm{NaH}_{2} \mathrm{PO}_{4}$, and 25 glucose, pH 7.4 (when bubbled with $95 \% \mathrm{O}_{2}$ and $5 \% \mathrm{CO}_{2}$ ).

\section{Patch-clamp recording from CGNs}

All experiments were performed at room temperature with $1 \mathrm{~mm}$ kynurenic acid and $30 \mu \mathrm{M}$ picrotoxin added to the external solution to block glutamatergic and GABAergic synaptic transmission. Other drugs, including $R$-(+)-methanandamide $(10 \mu \mathrm{M}), R-(+)$-WIN 55,212-2 [R-(+)-(2,3-dihydro-5-methyl-3-[(4-morpholinyl)methyl]pyrol[1,2,3de]-1,4- benzoxazin-6-yl)(1-naphthalenyl) methanone monomethanesulfonate] $(20 \mu \mathrm{M})$, and ruthenium red $(10 \mu \mathrm{M})$, were added to the bathing medium as indicated (all specialist drugs were supplied by Sigma). The pipette solution contained the following (in mM): $120 \mathrm{KCH}_{3} \mathrm{SO}_{4}, 4$ $\mathrm{NaCl}, 1 \mathrm{CaCl}_{2}, 1 \mathrm{MgCl}_{2}, 10 \mathrm{HEPES}, 5 \mathrm{EGTA}$, and $2 \mathrm{Mg}$-ATP, adjusted to $\mathrm{pH} 7.3$ with KOH. Granule cells were visualized using a Zeiss (Oberkochen, Germany) Axioscop 2FS fitted with Nomarski optics optimized for infrared video microscopy. Whole-cell recordings were made using either an Axopatch 200A or 700B amplifier (Molecular Devices, Union City, CA) run via a National Instruments (Austin, TX) digitization board on a dedicated personal computer. Data acquisition and anal- ysis was performed using WINWCP (version 3.3.3) kindly provided by John Dempster (University of Strathclyde, Glasgow, UK).

In the culture environment, presumptive CGNs were identified by their small soma size and characteristic electrophysiological properties. In cell-attached configuration, none of the chosen cells exhibited spontaneous action potentials consistent with the properties of granule cells in the acute slice preparation. At $2 \mathrm{~d}$ in culture, the granule cells chosen for whole-cell recording had an average soma diameter of $8.3 \pm 0.4 \mathrm{~mm}(n=$ 7 ) with few visible neurites. For cells $7 \mathrm{~d}$ in culture, the soma diameter was $8.5 \pm 0.5 \mathrm{~mm}(n=5)$, and, by $14 \mathrm{~d}$ in culture, the average soma diameter was $9.6 \pm 0.4 \mathrm{~mm}(n=7)$. By $14 \mathrm{~d}$ in culture, there was clear evidence of extensive neurite outgrowth, and, therefore, although there was no significant change in soma size, the membrane capacitance of cultured granule cells had increased from $5.0 \pm 0.8 \mathrm{pF}$ at $2 \mathrm{~d}$ in culture to $15.7 \pm$ $1.1 \mathrm{pF}$ at $14 \mathrm{~d}$ in culture. This increased capacitance presumably reflects the increased membrane area introduced after the considerable neurite outgrowth that has occurred in the culture conditions.

In whole-cell configuration, voltage-dependent $\mathrm{K}^{+}$currents were present at all stages, but clear $\mathrm{Na}^{+}$currents could only be consistently elicited from granule cells by $14 \mathrm{~d}$ in culture (peak inward $\mathrm{Na}^{+}$current, $0.9 \pm 0.2 \mathrm{nA}$ ). A fast A-type $\mathrm{K}^{+}$current was also detected at all ages, but the peak amplitude of this conductance was much increased by $14 \mathrm{~d}$ in culture. Together, these morphological and electrophysiological parameters clearly established the neuronal phenotype of the cells chosen. However, before application of glutamate and $\mathrm{GABA}_{\mathrm{A}}$ receptor antagonists, there was no evidence of spontaneous postsynaptic currents in any of cells examined. CGNs in the acute slice preparation would be expected to exhibit obvious signs of synaptic activity attributable to mossy fiber and Golgi cell inputs. Moreover, application of $\mathrm{GABA}_{\mathrm{A}}$ receptor antagonists did not alter the input conductance of cultured CGNs, demonstrating the absence of any tonic $\mathrm{GABA}_{\mathrm{A}}$ receptor-mediated conductance (data not shown). Therefore, as expected, cultured granule cells cannot be considered fully differentiated because they lack both glutamatergic and GABAergic synaptic inputs. In adult CGNs recorded from the acute slice preparation, the presence of a very slowly inactivating voltagedependent conductance (see Fig. $7 \mathrm{~A}$ ) with a time constant of $\sim 5 \mathrm{~s}$ meant that, unlike the situation in culture, $I_{\mathrm{K}(\mathrm{SO})}$ could only be analyzed after a $1 \mathrm{~min}$ control period with the cell held at $-20 \mathrm{mV}$. In all drug application studies, the control period immediately before drug application was compared with the value obtained once a steady-state value had been reached.

\section{Patch-clamp recording from tsA-201 cells}

Whole-cell currents were recorded from tsA-201 cells transiently transfected with expression plasmids encoding mTASK-3, hTASK-3, mTASK-1, and hTASK-1 channels. The composition of the control extracellular solution was as follows (in mM): $145 \mathrm{NaCl}, 2.5 \mathrm{KCl}, 3 \mathrm{MgCl}_{2}$, $1 \mathrm{CaCl}_{2}$, and $10 \mathrm{HEPES}$, titrated to $\mathrm{pH} 7.4$ with $\mathrm{NaOH}$. Glass microelectrodes were pulled from thick-walled borosilicate glass capillaries. Firepolished pipettes were backfilled with $0.2 \mu \mathrm{m}$ filtered intracellular solution (in mM: $150 \mathrm{KCl}, 3 \mathrm{MgCl}_{2}, 5 \mathrm{EGTA}$, and 10 HEPES, titrated to $\mathrm{pH} 7.4$ with $\mathrm{KOH})$. Voltage-clamp recordings were made using the whole-cell recording technique. Cells were usually held at $-80 \mathrm{mV}$ and then subjected to a step to $-40 \mathrm{mV}$ for $500 \mathrm{~ms}$, followed by a $500 \mathrm{~ms}$ voltage ramp from -80 to $+50 \mathrm{mV}$, once every $5 \mathrm{~s}$. Recordings were usually digitized at $10 \mathrm{kHz}$, and the record was filtered at $5 \mathrm{kHz}$. All electrophysiological measurements were performed at room temperature $\left(21-23^{\circ} \mathrm{C}\right)$.

\section{Behavioral studies}

Male TASK-1 KO and littermate wild-type mice (10-19 weeks old weighing 24-36 g) were maintained at the standard animal facilities in groups of one to four in polypropylene macrolon cages with food pellets and tap water available ad libitum. Lights were on from 6:00 A.M. to 6:00 P.M. Temperature and humidity were controlled at $20 \pm 1{ }^{\circ} \mathrm{C}$ and $50 \pm 10 \%$, respectively. All animal tests were approved by the Laboratory Animal Committee of the University of Helsinki. To investigate motor coordination and learning, the mice were trained for $6 \mathrm{~d}$ (three to six trials a day) to stay walking on a rotating rod (Rotamex 4/8; Columbus Instruments, Columbus, $\mathrm{OH}$ ) for $180 \mathrm{~s}$ while the rotation speed accelerated 


\section{Wild-type TASK-1 KO}

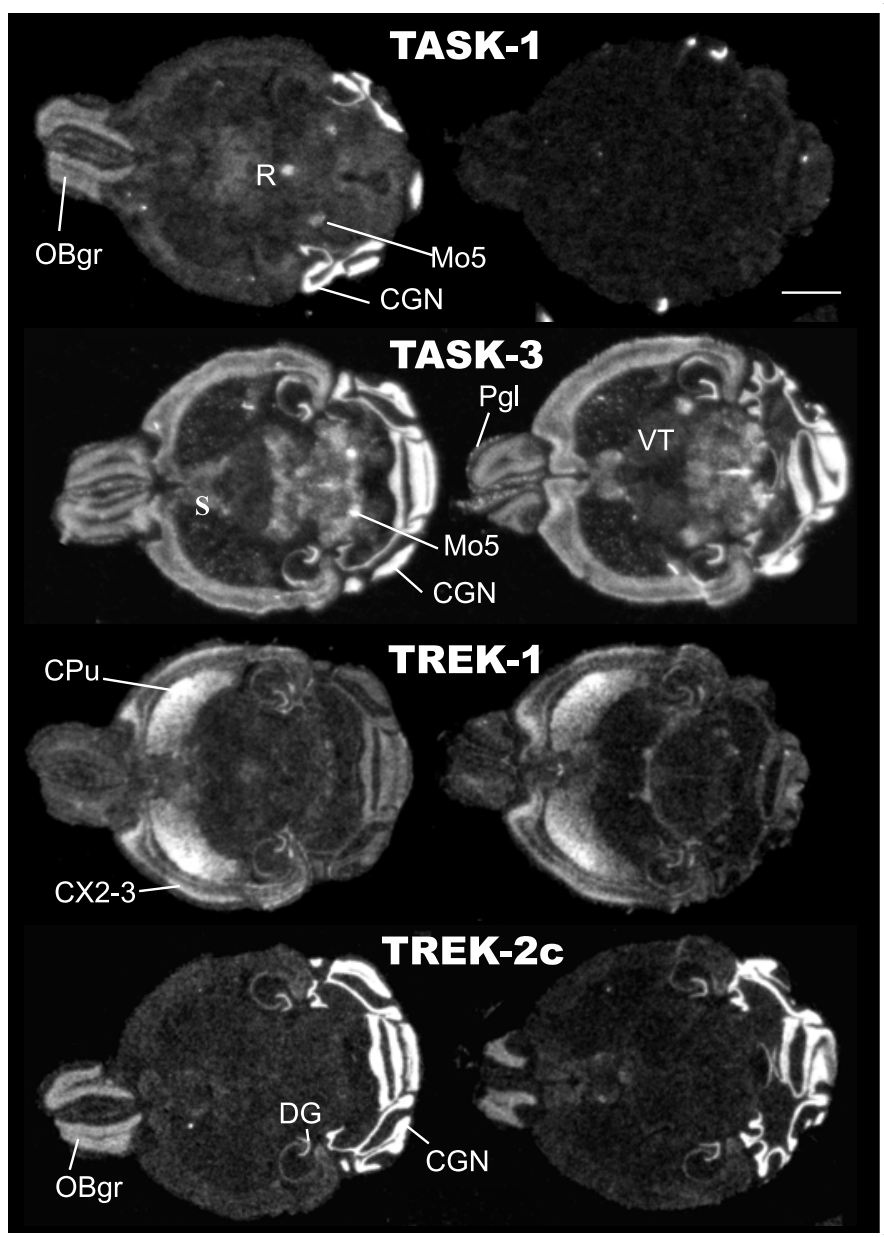

Wild-type TASK-1 KO

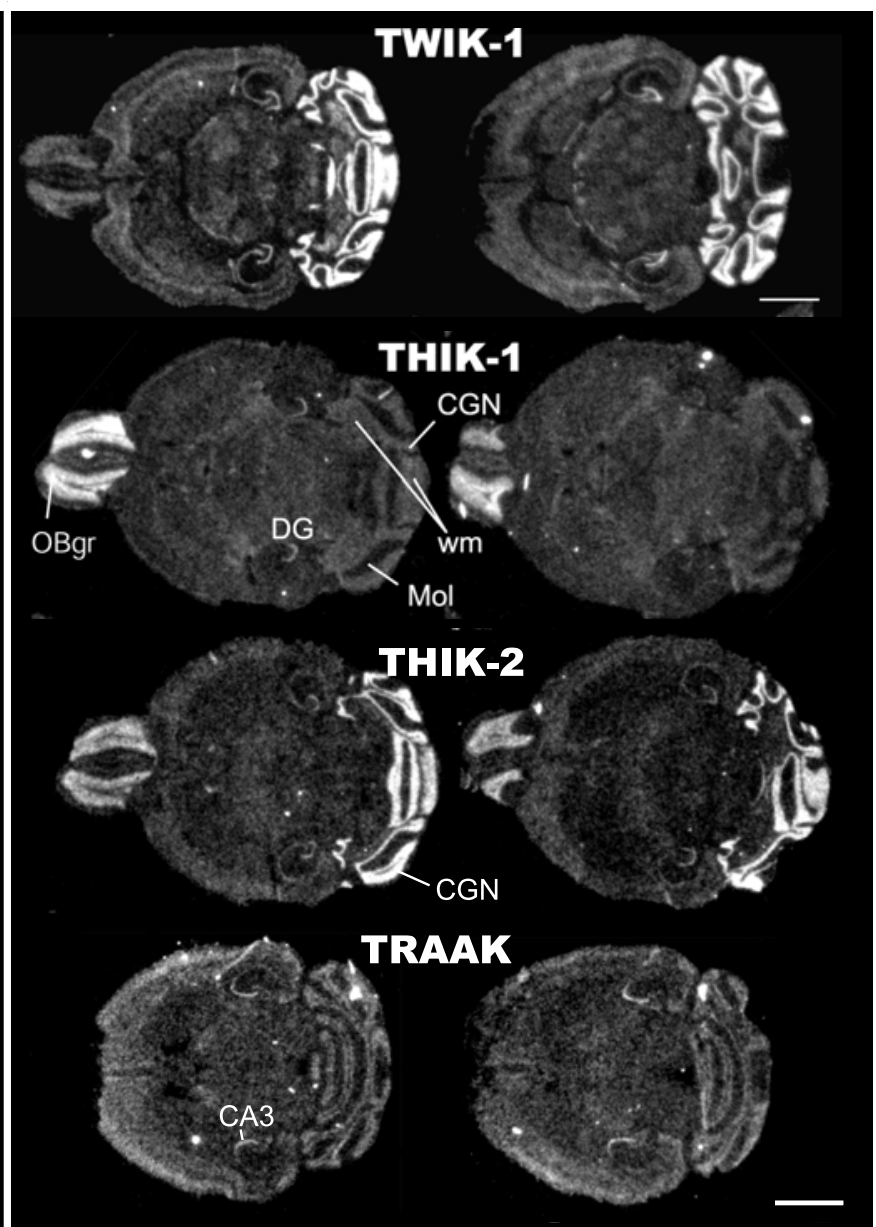

Figure 2. In situ hybridization of $\mathrm{K}_{2 \mathrm{P}}$ channels. In situ hybridization for eight members of the $\mathrm{K}_{2 \mathrm{P}}$ gene family in wild-type and TASK-1 K0 mouse brains. Mol, Molecular layer; wm, white matter; $\mathrm{R}$, raphe nuclei; OBgr, olfactory bulb granule cells; Pgl, periglomerular cells; M05, motor nuclei; $\mathrm{CX}$, neocortex; VT, ventral thalamus; CA3, hippocampal pyramidal cells; DG, hippocampal dentate granule cells; IC, inferior colliculi; CPu, caudate-putamen; S, septum. Scale bar, 2 mm.

from 5 to $40 \mathrm{rpm}$ (Korpi et al., 1998). The latency to fall from the rod in each trial was recorded, and a daily average performance was calculated for each animal. The mice were also trained to walk along $100-\mathrm{cm}$-long wooden beams ( 1.2 and $0.8 \mathrm{~cm}$ in diameter) back to their home cages. One end of the beam was mounted on a supporter and the other on the edge of the mouse home cage so that the beam was $84 \mathrm{~cm}$ above the floor. If the mouse did not move within $10 \mathrm{~s}$, it was gently pushed to move. If the mouse fell or was hanging, it was helped back on the top of the beam on the position where it was before. The latency to reach the other end of the beam and the number of falls (including hanging upside down) were recorded. The beam tests were performed once a day for $5 \mathrm{~d}$.

\section{Statistical analysis}

Statistical tests were performed using STATISTICA 5.1 (StatSoft, Tulsa, $\mathrm{OK}$ ) and considered significant at $p<0.05$. A Shapiro-Wilk test was used to determine whether measures were normally distributed, and differences between groups were examined using the Student's $t$ test or the Mann-Whitney $U$ test when distributions were not normal. Rotarod and beam-walking data were tested using repeated measures one-way ANOVA, followed by Dunnett's or Newman-Keuls post hoc tests.

\section{Results}

\section{Generation of a TASK-1 KO mouse}

We generated homozygote mice with an inactive TASK-1 gene (Fig. 1). It is clear from both in situ hybridization and real-time PCR with TASK-1 exon 2-specific primers (see Figs. 1-3) that the targeted TASK-1 allele is not expressed in the TASK-1 KO $(-/-)$ brain or heart (data not shown). The disrupted first exon normally encodes the first one-third of the TASK-1 channel protein up to the first potassium selectivity filter, residues GYG. Adult TASK-1 KO mice appear healthy, have a typical lifespan, and breed normally. No gross behavioral abnormalities were observed, and the size and morphology of both brain and heart appear normal in the mutants. We recognize that a complete phenotypic description of the TASK-1 KO would involve a quantitative analysis of heart, adrenal, and oxygen-sensing functions (Duprat et al., 1997; Kim et al., 1998; Bayliss et al., 2003). However, in the current description of the TASK-1 KO mouse, we concentrated on the functional impact of this genetic modification for CGNs.

Expression of the $\mathrm{K}_{2 \mathrm{P}}$ gene family in wild-type and TASK1 $\mathrm{KO}$ mouse brains

In situ hybridization on wild-type mouse brain sections shows that, in the brain, CGNs are the primary sites of TASK-1 gene expression (Fig. 1C), followed by the raphe nuclei, the olfactory bulb granule cells, and brainstem trigeminal motor nuclei, with considerably weaker TASK-1 gene expression in neocortex and thalamus (Fig. 2). A complete atlas of $\mathrm{K}_{2 \mathrm{P}}$ gene expression has so 
far only been published for the rat (Talley et al., 2001); although gene expression patterns are often similar between rodent species, this cannot be taken for granted, and there are some examples in which gene orthologs even differ strongly in their expression patterns between rodent subspecies (Young et al., 1999). As shown in Figure $2 B$, the series of in situ hybridizations describe the pattern of $\mathrm{K}_{2 \mathrm{P}}$ expression found in wild-type and TASK-1 KO mouse brain regions. Of the $10 \mathrm{~K}_{2 \mathrm{P}}$ channel mRNAs examined (see Materials and Methods), eight were evident in adult mouse CGNs. Of these, the TREK-2c splice form (Gu et al., 2002), TWIK-1, and THIK-2 were clearly expressed in CGNs at approximately the same level as the TASK-1 and TASK-3 genes, with much weaker granule cell signals detected for TREK-1, THIK-1, and TRAAK and no expression observed for TASK-2, TWIK-2, and TRESK (data not shown).

Although no clear TASK-2 signal has been reported previously in either rat or human brain using RT-PCR or in situ hybridization (Medhurst et al., 2001; Talley et al., 2001), TASK-2 antibodies are reported to give a strong signal in the rat cerebellum (Gabriel et al., 2002). As an alternative search for TASK-2 gene expression in the brain, we used TASK-2/lacZ gene trap mice (Mitchell et al., 2001; Warth et al., 2004). Although we could detect TASK-2-driven lacZ expression in the kidneys [in agreement with Warth et al. (2004)] and also in the dorsal root ganglia neurons of these animals [in agreement with the in situ hybridization data of Talley et al. (2001) for the rat nervous system], no lacZ expression was detectable in the brains and in particular the cerebellum (data not shown; TASK-2/lacZ mice were generously provided by R. Warth, University of Regensburg, Regensburg, Germany).

TASK-3 gene expression is more widely distributed throughout the brain than TASK-1, with strong expression in CGNs, hippocampal dentate granule cells, olfactory bulb granule cells and periglomerular cells, CA1 pyramidal cells, layers II and VI of neocortex, inferior colliculi, raphe nuclei, motor nuclei, and large interneurons (putative cholinergic) in the caudate-putamen. The TREK-2c variant and THIK-2 gene have expression patterns broadly similar to TASK-1 in the mouse brain, with their highest sites of expression occurring in CGNs, followed by olfactory bulb granule cells (Fig. $2 B$ ). However, there are clear differences in the expression of these genes. For example, the TREK-2c splice variant and THIK-2 mRNA are not clearly evident in the raphe or motor nuclei, although the TASK-1 and TASK-3 genes have strong expression in these areas. The TREK-1 gene has its highest expression in the caudate-putamen, with a striking lateral to medial expression gradient in that structure and two marked expression layers in the neocortex. TREK-1 is most likely not a major influence on mouse cerebellar function. THIK-1 is specifically expressed in the white matter tracts of the cerebellum, and possibly in other brain regions, at approximately the same low intensity as its expression in CGNs (the highest expression of THIK-1 in mouse brain is the olfactory bulb granule cells). Another feature worth noting for the mouse brain is that TASK-3 expression is quite similar to TWIK-1, with the notable exceptions of the caudate-putamen and septum. Relative to the other $\mathrm{K}_{2 \mathrm{P}}$ genes described here, the TRAAK gene seems barely expressed in the mouse brain, with expression mainly at a low level in CA3 pyramidal cells (Fig. 3), a quite different expression profile from that reported for the rat. However, no qualitative differences in these patterns of expression were observed between wild-type and TASK-1 KO brains. In agreement with previous studies in the mouse (Brickley et al., 2001) and rat (Karschin et al., 2001; Talley et al., 2001), it would appear that CGNs are an important site for TASK-1 expression. However, because CGNs express at least seven other $\mathrm{K}_{2 \mathrm{P}}$ channel genes, albeit some at low levels, the generation of $I_{\mathrm{K}(\mathrm{SO})}$ in these cells could result from a heterogeneous channel population.

\section{Quantitative analysis of $\mathrm{K}_{2 \mathrm{P}}$ expression in TASK-1 KO mice}

Real-time quantitative PCR was used to examine possible changes in $\mathrm{K}_{2 \mathrm{P}}$ expression as a result of silencing the TASK-1 gene. Apart from the loss of TASK-1 mRNA in the TASK-1 KO, we could detect no significant difference in the steady-state transcript levels of other $\mathrm{K}_{2 \mathrm{P}}$ family members in the cerebellum of TASK-1 KO and wild-type littermate mice. A similar result was obtained in a series of parallel experiments in which we analyzed tissue from the forebrain (data not shown). Although we could not detect TASK-2 mRNA by in situ hybridization in the adult mouse brain or by using the TASK-2/lacZ gene trap mouse line (data not shown), we could obtain a TASK-2 signal by real-time PCR, albeit using a 10-fold higher input concentration of cerebellar cDNA than for the other $\mathrm{K}_{2 \mathrm{P}}$ genes. However, this very low level of TASK-2 signal did not differ between wild-type littermates and TASK-1 KO mice (Fig. 3). A low level of TRESK gene expression has been reported using conventional RT-PCR in the mouse cerebellum (Czirjak et al., 2004), but, in our hands, even using 25-fold more input cerebellar cDNA in the real-time PCR assay, we could only detect weak TRESK gene expression in either wild-type or TASK-1 KO cerebellum that was hard to resolve from the background signal (data not shown).

As a positive control. we also looked at changes in TASK 

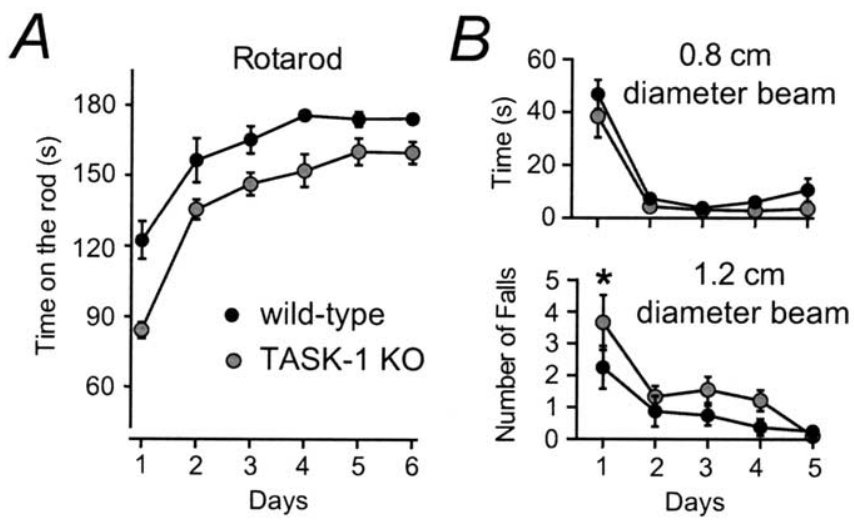

Figure 4. Behavioral deficits in the TASK-1 knock-out mice. A, TASK-1 KO $(-/-)$ mice stayed shorter times on the rotating rod than wild-type $(+/+)$ littermates, but both strains improved their performance during a training period. Mice were trained for $6 \mathrm{~d}$ ( $3-6$ trials a day). In each 3 min trial, the rotation speed was accelerated from 5 to $40 \mathrm{rpm}$. Repeatedmeasures one-way ANOVA confirmed that the genotype effect on the rotarod performance was significant $\left(F_{(1,112)}=14.92 ; p<0.01\right)$. $\boldsymbol{B}$, The latency to walk along the 100 -cm-long horizontally placed beam of $1.2 \mathrm{~cm}$ diameter back to the home cage. The number of falls from the 100 -cm-long horizontally placed beam of $0.8 \mathrm{~cm}$ diameter during walk back to the home cage. Data are means \pm SEM $(n=7-9) ;{ }^{*} p<0.05$.

mRNA levels that are known to occur in an $\alpha 6 \mathrm{GABA}_{\mathrm{A}}$ receptor $\mathrm{KO}$ strain in which a tonic $\mathrm{GABA}_{\mathrm{A}}$ receptor-mediated conductance is selectively removed from CGNs (Brickley et al., 2001). As shown in Figure $3 B$, real-time PCR demonstrated that TASK-1 mRNA levels increased twofold and TASK-3 mRNA levels $\sim 1.7$ fold in $\alpha 6 \mathrm{KO}$ cerebella, consistent with our previous findings (Brickley et al., 2001). We are, therefore, confident that this PCR assay should have been sufficiently sensitive to detect any changes in $\mathrm{K}_{2 \mathrm{P}}$ mRNA expression, had they occurred, in the TASK-1 KO strain. We then proceeded to use real-time PCR to examine any significant changes in expression level for the $\alpha 6$ and $\delta$ subunits of the $\mathrm{GABA}_{\mathrm{A}}$ receptor family in the TASK-1 KO (Fig. 3C). It could be that the receptors responsible for the tonic $\mathrm{GABA}_{\mathrm{A}}$ receptor-mediated conductance have increased their expression levels to compensate for the loss of the TASK-1-mediated conductance in an analogous manner to that observed in the $\alpha 6 \mathrm{KO}$ mice (Brickley et al., 2001). However, at least at the mRNA level, it would appear that we have no evidence for subunit compensations having occurred in the TASK-1 KO mice.

\section{Motor deficits in TASK-1 KO mice}

Observations of locomotor activity in an open-field test revealed little qualitative difference between TASK-1 KOs and their wildtype littermates. For example, when placed in a novel cage with squares marked on the floor, the wild-type mice entered $22.6 \pm$ $2.3(n=16)$ squares in $30 \mathrm{~s}$, whereas TASK-1 KO mice entered $23.3 \pm 1.9(n=19)$ in the same time period, showing identical exploratory locomotor activity. It was also clear from these tests that there was no evidence of ataxia, tremor, or gait abnormalities in TASK-1 KO mice.

To explore cerebellar function, we applied the accelerating rotarod assay to examine balance and coordination in more detail (Jones and Roberts, 1968). Training on a rotarod, accelerating in $180 \mathrm{~s}$ from slow $5 \mathrm{rpm}$ to very high $40 \mathrm{rpm}$, showed that the TASK-1 KO mice were less able to stay on the rotating rod than wild-type mice (Fig. 4A). On the first day of training, wild-type mice remained on the rotating rod for $2 \min (122 \pm 8 \mathrm{~s} ; n=9)$ compared with $84 \pm 3$ s for TASK- 1 KO mice $(n=10)$. By $4 \mathrm{~d}$ of training, the wild-type mice were able to maintain balance prac- tically for the full 3 min of testing, whereas TASK-1 KO mice did not reach this level of proficiency during $6 \mathrm{~d}$ of training. Repeated-measures one-way ANOVA confirmed that the genotype effect on the rotarod performance was significant $\left(F_{(1,112)}=\right.$ $14.92 ; p<0.01)$. A significant training effect $\left(F_{(1,112)}=71.34 ; p<\right.$ $0.001)$ and an interaction between training and genotype $\left(F_{(1,112)}=2.35 ; p<0.05\right)$ were also observed.

Motor coordination and balance were further studied using a beam-walking test with another cohort of TASK-1 KO mice and littermate wild-type $(+/+)$ controls. Both genotypes learned after $1 \mathrm{~d}$ training to walk along the wider beam $(1.2 \mathrm{~cm}$ in diameter) back to their home cage in few seconds (Fig. $4 B$ ). Only occasional falls were observed during a $5 \mathrm{~d}$ training on the wider beam, totaling three in wild-type mice $(n=8)$ and four in TASK-1 KO mice $(n=9)$. Walking on the narrower beam $(0.8 \mathrm{~cm}$ in diameter) was more difficult and revealed a significant genotype effect $\left(F_{(1,83)}=6.46 ; p<0.05\right)$ in the number of falls, the TASK-1 KO mice falling from the beam more frequently than wild-type mice (Fig. 4C). From these behavioral assays, it would appear that TASK-1-containing $\mathrm{K}_{2 \mathrm{P}}$ channels are not obligatory for motor learning, because the rotarod and beam-walking performance was improved by daily practice in both TASK-1 KOs and controls, but loss of TASK-1 channels does appear to have a significant impact on motor coordination or balance.

\section{No change in the magnitude of $I_{\mathrm{K}(\mathrm{SO})}$ in TASK-1 KO mice}

A standing outward current was present in CGNs recorded from both the acute slice preparation and the culture environment (Fig. 5A). The developmental emergence of $I_{\mathrm{K}(\mathrm{SO})}$ was first demonstrated in cultured rat CGNs by Watkins and Mathie (1996) and has been reported in several subsequent studies (Brickley et al., 2001; Han et al., 2002). We also find that the magnitude of $I_{\mathrm{K}(\mathrm{SO})}$ is developmentally regulated in both the culture and slice preparation. This increase in $I_{\mathrm{K}(\mathrm{SO})}$ correlates with the developmental upregulation of $\mathrm{K}_{2 \mathrm{P}}$ channels such as TASK-1 and TASK-3 (Millar et al., 2000; Brickley et al., 2001; Han et al., 2002). Although our results from the culture and slice preparations are essentially complementary, they also demonstrate that important differences exist between these preparations. For example, the slowly inactivating voltage-dependent conductance that we reported previously in the slice preparation (Brickley et al., 2001) was never observed in the culture preparation (Fig. $5 A$, compare trace $i$ with traces $i i-i v)$.

The developmental emergence of $I_{\mathrm{K}(\mathrm{SO})}$ explains the increased input conductance of CGNs in both the culture and slice preparation. The increase in $I_{\mathrm{K}(\mathrm{SO})}$ quantified in Figure 6, $A$ and $B$, explains the observed changes in CGN cell input conductance in both the culture $[0.7 \pm 0.3 \mathrm{nS}(n=6)$ at $2 \mathrm{~d}$ in culture, $1.0 \pm 0.1$ $\mathrm{nS}(n=5)$ at $7 \mathrm{~d}$ in culture, and $2.3 \pm 0.3 \mathrm{nS}(n=12)$ at $14 \mathrm{~d}$ in culture $]$ and the acute slice preparation $[0.2 \pm 0.02 \mathrm{nS}(n=7)$ at $\mathrm{P} 7,0.6 \pm 0.2 \mathrm{nS}$ at P14 $(n=18), 1.1 \pm 0.1 \mathrm{nS}(n=13)$ at P35, and $1.4 \pm 0.1 \mathrm{nS}(n=21)$ at P75]. The increased potassium permeability resulting from this conductance is thought to be responsible for the hyperpolarized resting membrane potential of adult granule cells $(-57.0 \pm 1.8 \mathrm{mV}$ at $\mathrm{P} 7 \mathrm{vs}-82.6 \pm 0.9 \mathrm{mV}$ at P75). As shown in Figure $5 B$, the external $\mathrm{K}^{+}$concentration was altered to examine the relationship between the potassium equilibrium potential and the reversal potential of the leak conductance in adult granule cells. As shown in Figure $5 C$, the reversal potential of the leak conductance was entirely determined by the $\mathrm{K}^{+}$equilibrium potential, as calculated from the Nernst equation, indicating that the resting membrane potential of CGNs will be primarily determined by the magnitude of $I_{\mathrm{K}(\mathrm{SO})}$. Because TASK-1 
channel expression has often been correlated with the emergence of $I_{\mathrm{K}(\mathrm{SO})}$, it was expected that the magnitude of this conductance would be reduced in the TASK-1 $\mathrm{KO}$, and this should have a significant impact on granule cell excitability.

However, there was little difference in the basic properties of wild-type and TASK-1 KO granule cells in the adult slice preparation (P75 $\pm 15 \mathrm{~d}, n=15$ wild-type mice vs $\mathrm{P} 97 \pm 20 \mathrm{~d}, n=8$ TASK- $1 \mathrm{KO}$ mice). The initial seal resistance in cellattached configuration was $4.5 \pm 0.3 \mathrm{G} \Omega$ in wild-type $(n=40)$ versus $5.8 \pm 0.8 \mathrm{G} \Omega$ in TASK-1 KO granule cells $(n=23)$. In whole-cell configuration, the membrane capacitance $(2.8 \pm 0.2 \mathrm{pF}$ in wild-type cells vs $3.2 \pm 0.3 \mathrm{pF}$ in TASK- $1 \mathrm{KO}$ cells) and input conductance $(1.4 \pm 0.09$ vs $1.4 \pm 0.1$ $\mathrm{nS}$ ) was similar between strains, as was the resting membrane potential $(-82.6 \pm 0.9$ $\mathrm{mV}, n=20$ vs $-84.5 \pm 2.1 \mathrm{mV}, n=10)$ (Fig. 6C, inset). Standard voltage step protocols were used to isolate specific voltagedependent ion channel families and compare their properties between strains (data not shown). No significant difference was observed in the properties of any voltagegated current examined. For example, the peak inward $\mathrm{Na}^{+}$current was $-1.3 \pm 0.2$ $\mathrm{nA}(n=18)$ in wild-type CGNs compared with $-0.9 \pm 0.2 \mathrm{nA}(n=6)$ in the TASK- 1 KO. When examining the outward currents, the transient A-type and standard delayed rectifier were $1.1 \pm 0.2$ and $-1.0 \pm 0.2 \mathrm{nA}(n=18)$, respectively, in wild-type CGNs compared with $1.1 \pm 0.2$ and $-1.0 \pm 0.2 \mathrm{nA}(n=6)$ in the TASK-1

KO. Also, the slowly inactivating voltage-dependent outward current observed in mature CGNs was no different in either peak amplitude at $-20 \mathrm{mV}(677.4 \pm 273.0 \mathrm{pA}, n=14$ in wild-type vs $736.0 \pm 125.1 \mathrm{pA}, n=21$ in the TASK-1 KO) or decay kinetics $(6.4 \pm 0.7 \mathrm{~s}, n=14$ in wild-type vs $6.1 \pm 0.6 \mathrm{~s}, n=21$ in the TASK-1 KO). Consistent with these findings, a series of currentclamp experiments demonstrated that the firing properties of adult CGNs were not altered in the TASK-1 KO mice (Fig. $6 D$ ). For example, the current required to reach action potential threshold was not different $(16.4 \pm 1.6 \mathrm{pA}, n=9$ in wild-type vs $16.4 \pm 2.9 \mathrm{pA}, n=9$ in TASK-1 KO), and, once threshold had been reached, the relationship between injected current and action potential frequency was $4.8 \pm 0.4 \mathrm{~Hz} / \mathrm{pA}$ in wild-type CGNs $(n=9)$ compared with $5.4 \pm 0.8 \mathrm{~Hz} / \mathrm{pA}$ in the TASK-1 KO mice $(n=9)$.

As shown in Figure 6, we could not detect any difference in the magnitude of $I_{\mathrm{K}(\mathrm{SO})}$ between wild-type and TASK-1 KO cells at any stage examined in ether the culture or the acute slice preparation. A ramp protocol from -20 to $-160 \mathrm{mV}$ was used to isolate the voltage-independent potassium current or $I_{\mathrm{K}(\mathrm{SO})}$ in the presence of the various receptor antagonists (see Materials and Methods). The shape of the current-voltage relationship during the ramp protocol appeared similar in the two strains (Fig. $6 B)$. On further examination, the magnitude of $I_{\mathrm{K}(\mathrm{sO})}$ at $-20 \mathrm{mV}$ was found to be no different between the two strains $(36.8 \pm 1.6$
pA/pF. $n=40$ in wild-type cells vs $38.2 \pm 3.6 \mathrm{pA} / \mathrm{pF}, n=22$ in TASK-1 KO cells) as was the reversal potential of this current. Therefore, from these experiments, it was clear that inactivation of the TASK-1 gene did not alter the intrinsic excitability of adult CGNs.

An assay of TASK- 1 and TASK- 3 contribution to $I_{\mathrm{K}(\mathrm{SO})}$

It is possible that the contribution of other $\mathrm{K}_{2 \mathrm{P}}$ channels, such as TASK-3, has altered in TASK-1 KO granule cells leading to a normalization of $I_{\mathrm{K}(\mathrm{SO})}$. Therefore, it was necessary to establish diagnostic assays of $\mathrm{K}_{2 \mathrm{P}}$ channel function that distinguished between subunit types. By simply altering external $\mathrm{pH}$, it should be possible to distinguish between TASK-1- and TASK-3-mediated currents (Duprat et al., 1997; Kim et al., 2000; Lopes et al., 2000; Rajan et al., 2000; Czirjak and Enyedi, 2002; Kang et al., 2004). However, previous experiments on the $\mathrm{pH}$ sensitivity of $\mathrm{K}_{2 \mathrm{P}}$ channels were performed using rat or human clones, and so we needed to demonstrate that mouse TASK channels behaved in a similar manner. As shown in Figure 7A, when mouse cDNA clones encoding TASK-1 channels were expressed, the voltageindependent leak conductance present in these cells was sensitive to both external acidification and alkalization. After a shift to $\mathrm{pH}$ 6.4 , the leak conductance was inhibited by $75 \pm 4 \%(n=5)$, and, at $\mathrm{pH} 8.4$, the leak conductance was enhanced by $96 \pm 8 \%(n=$ 5). However, when mouse TASK- 3 channels were expressed, the leak conductance was no longer sensitive to external alkalization 
$A$

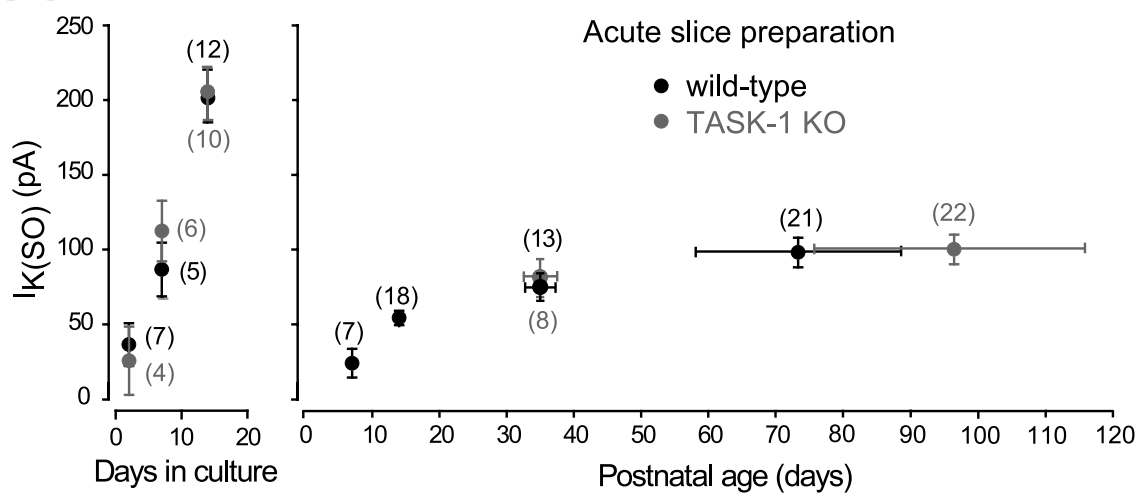

C

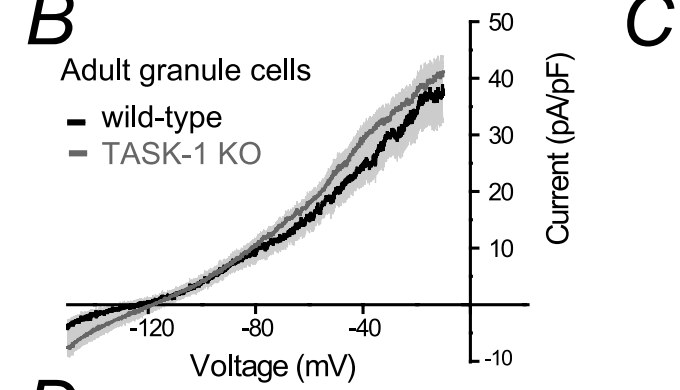

$D$

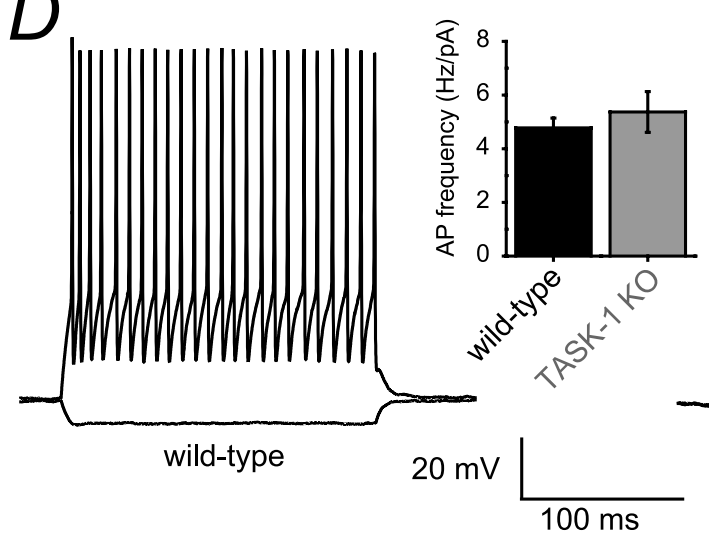

Figure 6. Comparison of $I_{\mathrm{K}\left(\mathrm{S}_{0}\right)}$ recorded from CGNs in wild-type and TASK-1 KO mice. $\boldsymbol{A}$, Left plot is a comparison of $I_{\mathrm{K}(S 0)}$ measured at $-20 \mathrm{mV}$ immediately before the ramp protocol recorded from granule cells at 2, 7, and $14 \mathrm{~d}$ in culture, prepared from either wild-type (black) or TASK-1 KO (gray) mice. No significant difference between the magnitude of $I_{\mathrm{K}(\mathrm{S} 0)}$ was observed between these strains at any stage in culture. The right plot illustrates the magnitude of $I_{\mathrm{K}\left(5_{0}\right)}$ measured at $-20 \mathrm{mV}$ from wild-type granule cells (black) at different ages in the acute slice preparation. Once again, there was no difference in the magnitude of $\left.\right|_{K(S O)}$ recorded from TASK- $1 \mathrm{KO}$ (gray) mice. $\boldsymbol{B}$, Comparison of current-voltage relationships between wild-type (black) and TASK-1 KO (gray) granule cells recorded from the adult slice preparation. The current-voltage plots are averages from each strain with the mean \pm SEM superimposed. C, A plot of the resting membrane potential (RMP) of the cells included in the currentvoltage plot in $\boldsymbol{B}$. There was no significant difference between the data obtained from wild-type and TASK-1 K0 granule cells. $\boldsymbol{D}$, Current-clamp recordings from CGNs from wild-type (left) and TASK-1 KO (right) mice. In each case, the response to a hyperpolarizing $(8 \mathrm{pA})$ and depolarizing $(30 \mathrm{pA})$ current injection step have been superimposed. The relationship between injected current and action potential frequency for CGNs in each strain have been plotted in the bar graph. As predicted form the voltage-clamp experiments, there was no significant difference in the data obtained from the two strains.

( $2 \pm 1 \%$ reduction $n=7$ ), although a clear block was still observed during external acidification ( $41 \pm 4 \% ; n=9)$. Recent recombinant expression data suggest that the blocking action of $\mathrm{Zn}^{2+}$ is also a useful diagnostic of TASK-3 channel function (Clarke et al., 2004). As shown in Figure 7B, this situation is also true for mouse TASK channels, and, at physiological pH, $100 \mu \mathrm{M}$ $\mathrm{Zn}^{2+}$ significantly blocks TASK-3-mediated currents $(86 \pm 3 \%$; $n=7)$, with little effect on TASK- 1 channels $(-10 \pm 2 \%$ change; $n=4$; not significant). Ruthenium red has also been shown, in recombinant expression studies, to block TASK-3 homodimeric channels with no reported action on TASK-1-containing $\mathrm{K}_{2 \mathrm{P}}$ channels (Czirjak and Enyedi, 2002, 2003). Once again, it was necessary to replicate this finding using mouse clones. As shown in Figure $7 C, 10 \mu \mathrm{M}$ ruthenium red had little action on TASK-1-mediated currents $(-4 \pm 5 \%$ change; $n=4$; not significant) but significantly reduced ( $65 \pm 2 \%$; $n=10)$ the current attributable to TASK3-containing channels.

In a series of parallel experiments, the action of $\mathrm{Zn}^{2+}$, ruthenium red, and external $\mathrm{pH}$ were directly compared between mouse and human clones. No significant difference in the blocking action of $\mathrm{Zn}^{2+}$ and ruthenium red or the enhancement by external alkalization was observed between human and mouse clones (Fig. 7A$C)$. Another signature of TASK- 1 channel function was reported to be the selective blocking action of cannabinoid agonists such as methanandamide or $R$ - $(+)$-WIN 55,212-2 (Maingret et al., 2001). However, we and others (Berg et al., 2004) have found no difference in the potency of these drugs at inhibiting TASK-1 and TASK-3 channels in mouse, human, or rat clones (data not shown). Together, our recombinant expression studies demonstrate that extracellular alkalization and the addition of zinc or ruthenium red should provide a useful diagnostic fingerprint for comparing the contribution of TASK-1- and TASK-3-containing channels to native leak currents such as $I_{\mathrm{K}(\mathrm{SO})}$. Thus, we have shown that mouse TASK-1 and TASK-3 have an identical pharmacological fingerprint to the corresponding human and rat clones, this despite quite significant sequence differences, particularly for TASK-3, between human, on the one hand, and rat and mouse, on the other.

Although we did not generate functional mouse TASK-1/TASK-3 forced concatamers, the similarity of pharmacology across species allows us to draw on information from studies of human and rat TASK-1/TASK-3 forced concatamers (with the caveat that forced concatamers may not precisely recapitulate the functional properties of naturally occurring heterodimers). From such studies, it has been shown that TASK-1/TASK-3 heterodimers have little or no sensitivity to ruthenium red or $\mathrm{Zn}^{2+}$ (Czirjak and Enyedi, 2002; Berg et al., 2004; Clarke et al., 2004; Kang et al., 2004) but an intermediate sensitivity (between TASK-1 and TASK-3) to changes in pH (Czirjak and Enyedi, 2002; Kang et al., 2004).

In light of these findings, we examined whether the $\mathrm{pH}$ modulation of $I_{\mathrm{K}(\mathrm{SO})}$ in adult CGNs had been altered in the TASK-1 KO. No significant difference in the degree of block after external acidification from a $\mathrm{pH}$ of 7.4-6.4 was observed between strains. 
In wild-type CGNs, a $25 \pm 6 \%(n=5)$ block was observed compared with $28 \pm$ $9 \%(n=4)$ block in the TASK-1 KO. Adult granule cells were then exposed to a $\mathrm{pH}$ shift from 7.4 to 8.4 , and the magnitude of $I_{\mathrm{K}(\mathrm{SO})}$ was monitored. As shown in Figure $8 A$, a significant $29 \pm 5 \%(n=5)$ enhancement of $I_{\mathrm{K}(\mathrm{SO})}$ was observed in wildtype granule cells, with no significant change $(6 \pm 4 \%$; $n=4)$ in $I_{\mathrm{K}(\mathrm{SO})}$ recorded from TASK-1 KO cells.

Subsequently, we examined the blocking action of the TASK-3-selective blocker $\mathrm{Zn}^{2+}$ on $I_{\mathrm{K}(\mathrm{SO})}$ (Fig. $8 \mathrm{~B}$ ). In wild-type granule cells, we could not detect any block with $100 \mu \mathrm{M} \mathrm{Zn}^{2+}$, whereas a significant $37 \pm 5 \%(n=6)$ block of $I_{\mathrm{K}(\mathrm{SO})}$ was observed in TASK-1 KO cells. As shown in Figure $8 C$, at a concentration of $10 \mu \mathrm{M}$, ruthenium red had no significant action on $I_{\mathrm{K}(\mathrm{SO})}$ recorded from wild-type adult granule cells $(n=4)$, but, in TASK-1 KO mice, $10 \mu \mathrm{M}$ ruthenium red significantly blocked $I_{\mathrm{K}(\mathrm{SO})}$ by $31.4 \pm 4.5 \%(n=6)$. Together, these results would suggest that TASK-1-containing $\mathrm{K}_{2 \mathrm{P}}$ channels do contribute to the $\mathrm{pH}$-sensitive component of $I_{\mathrm{K}(\mathrm{SO})}$ in adult granule cells, but this conductance has been replaced by a TASK-3 homodimeric channel population in the TASK-1 KO strain.

\section{Discussion}

This study describes several novel aspects of TASK-1 channel function, demonstrating the role $\mathrm{K}_{2 \mathrm{P}}$ channels play in the control of CGN excitability. The general behavior of TASK-1 KO mice was normal, but motor performance, as assayed using the accelerating rotarod and walkingbeam tests, was impaired. A number of studies have discussed the importance of TASK-1 channel expression for the generation of $I_{\mathrm{K}(\mathrm{SO})}$ in CGNs, particularly in the neonatal (primary) culture preparation (Millar et al., 2000; Han et al., 2002; Cotton et al., 2004; Kang et al., 2004). Given the high level of TASK-1 gene expression found in wild-type CGNs, it was a surprise to find that several indicators of intrinsic excitability were not affected by the removal of TASK-1. In particular, the magnitude of the potassium leak conductance, $I_{\mathrm{K}(\mathrm{SO})}$, was similar in wild-type and TASK-1 KO CGNs. However, on further examination, it was found that the modulation of $I_{\mathrm{K}(\mathrm{SO})}$ by external protons and $\mathrm{Zn}^{2+}$ was altered, attributable to a change in the subunit composition of the $\mathrm{K}_{2 \mathrm{P}}$ channels responsible for the generation of this conductance.

The subunit composition of $\mathrm{K}_{2 \mathrm{P}}$ channels contributing to $I_{\mathrm{K}(\mathrm{SO})}$ Our data would suggest that, in adult CGNs in situ, the majority of channels contributing to the $\mathrm{pH}$-sensitive component of $I_{\mathrm{K}(\mathrm{SO})}$ are heterodimers made up from TASK-1 and TASK-3 subunits. The enhancement of $I_{\mathrm{K}(\mathrm{SO})}$ that occurred in wild-type CGNs after external alkalization and the loss of this response in the TASK-1 $\mathrm{KO}$ is consistent with the formation of TASK-3 homodimers after the removal of TASK-1. In adult wild-type CGNs, external alka- lization enhanced $I_{\mathrm{K}(\mathrm{SO})}$ by $\sim 30 \%$ compared with more than $80 \%$ when homodimers of TASK-1 were exposed to a similar $\mathrm{pH}$ shift in recombinant expression systems. The modest increase in $I_{\mathrm{K}(\mathrm{SO})}$ observed in the wild type is consistent with the presence of TASK-1/TASK-3 heterodimers. The fact that acidification blocked $I_{\mathrm{K}(\mathrm{SO})}$ to a similar extent in both strains is also more consistent with a heterodimeric TASK-1/TASK-3 channel population in the wild type, because a more substantial difference would be expected if a homodimeric TASK-1 population were replaced by a homodimeric TASK-3 population. Moreover, if TASK-3 homodimers were present in adult CGNs, we would also expect $I_{\mathrm{K}(\mathrm{SO})}$ to be $\mathrm{Zn}^{2+}$ sensitive. TASK-3 mRNA is highly abundant within CGNs, but, in the adult cerebellum at least, $\mathrm{Zn}^{2+}$ sensitivity was only observed in TASK-1 KO granule cells, demonstrating that homodimers of TASK-3 will only form in the absence of TASK-1 subunits. Ruthenium red sensitivity was also only observed in the TASK-1 KO, consistent with its selective action on TASK-3 homodimeric channels.

Most previous studies investigating $\mathrm{K}_{2 \mathrm{P}}$ subunit composition in CGNs have been performed using the primary culture preparation. Data from these neonatal culture preparations suggest the 
A

Wild-type

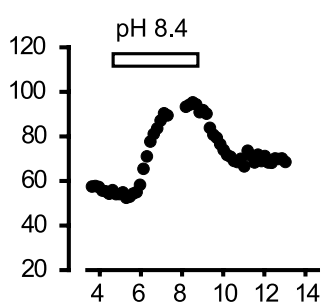

$B$

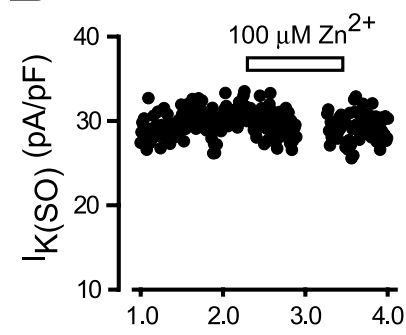

C

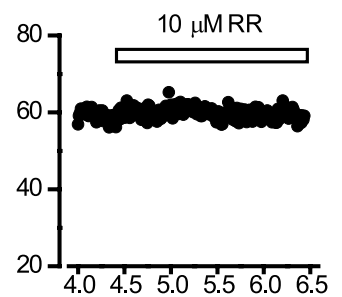

TASK-1 KO
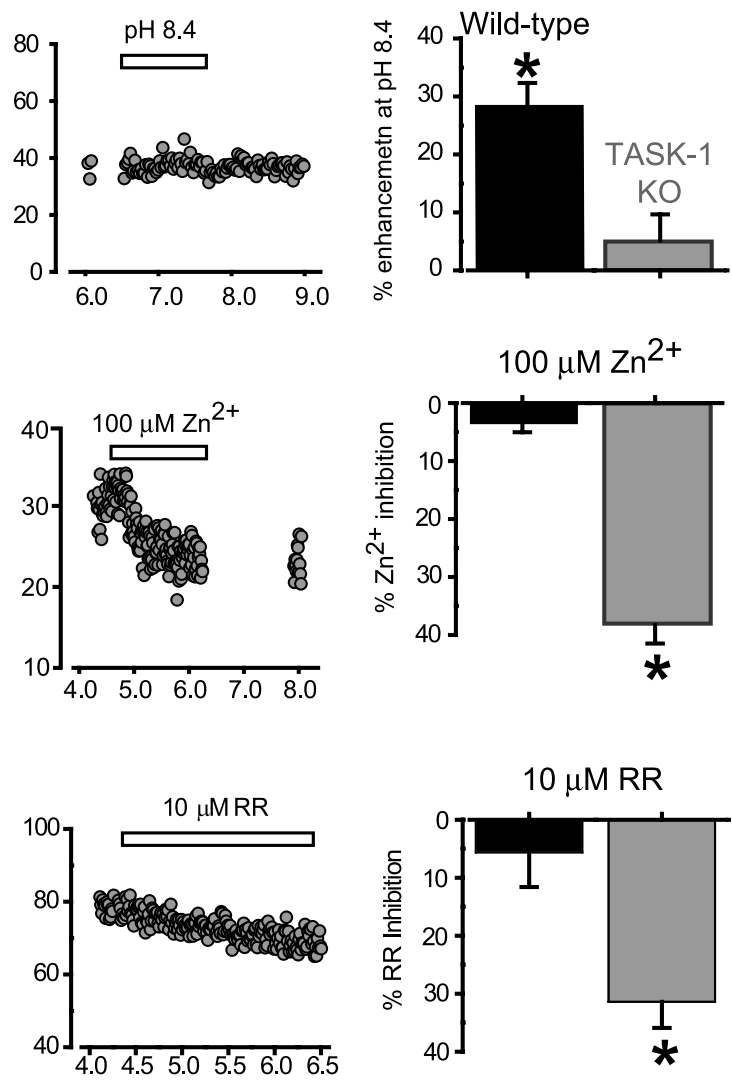

Time after breakthrough ( $\mathrm{min})$

Figure 8. Altered properties of $I_{\mathrm{K}(\mathrm{SO})}$ in TASK-1 KO adult CGNs. $A$, Plot of $I_{\mathrm{K}(\mathrm{S} 0)}$ measured at $-20 \mathrm{mV}$ from wild-type and TASK-1 $\mathrm{KO}$ adult granule cell during a transient change in external $\mathrm{pH}$ from 7.4 to 8.4. The graph on the right illustrates the average data from all granule cells exposed to external alkalization. Note the significant increase in $I_{\mathrm{K}\left(\mathrm{S}_{0}\right)}$ recorded from wild-type granule cells but no change in $I_{K(S O)}$ in TASK-1 KO granule cells. $B, C$, Conventions are the same as in $\boldsymbol{A}$, but results were obtained after addition of $100 \mu \mathrm{m} \mathrm{Zn}^{2+}$ and $10 \mu \mathrm{m}$ ruthenium red (RR). In both cases, a significant reduction in $I_{\mathrm{K}(\mathrm{SO})}$ was observed in recordings from TASK-1 KO granule cells, with no change in $I_{\mathrm{K}(\mathrm{SO})}$ recorded from wild-type granule cells. Data are mean $\pm \mathrm{SEM}$; ${ }^{*} p<0.05$.

presence of at least four types of TASK-like channels (Han et al., 2002; Cotton et al., 2004; Kang et al., 2004). This heterogeneity was explained by the presence of both homodimers and heterodimers made up from different TASK-1, TASK-2, and TASK-3 subunit combinations. However, consistent with other studies (Karschin et al., 2001; Medhurst et al., 2001; Talley et al., 2001), our in situ hybridization data failed to demonstrate TASK-2 mRNA in adult CGNs. This apparent inconsistency may result from the use of the primary culture preparation. As shown in Figure $5 A$, the electrophysiological properties of CGNs in the primary culture preparation do not correspond well to those found in the adult slice preparation, presumably reflecting the immature stage of development of the cultured CGNs. It is therefore not surprising that the contribution of the various TASK channels to $I_{\mathrm{K}(\mathrm{SO})}$ is different in the culture preparation (Fig. $6 \mathrm{~A}$ ). For example, consistent with previous data in culture (Lauritzen et al., 2003; Clarke et al., 2004), we also find that $I_{\mathrm{K}(\mathrm{SO})}$ is sensitive to external $\mathrm{Zn}^{2+}$ application in cultured wild-type CGNs. At $14 \mathrm{~d}$ in culture, application of $100 \mu \mathrm{M} \mathrm{Zn}{ }^{2+}$ inhibits $I_{\mathrm{K}(\mathrm{SO})}$ by $46.2 \pm$ $3.4 \%(n=5)$ in wild-type CGNs (data not shown), demonstrating the presence of TASK-3 homodimers. This contrasts to the situation in wild-type CGNs recorded from the adult slice prep- aration in which we find no evidence of homodimeric TASK-3 channels (see above).

It could be that, in the neonatal brain, there is more heterogeneity in the TASK channel types present. In support of this suggestion, Berg et al. (2004) found that, in juvenile motor neurons recorded from acute slices, the leak conductance comprised $\sim 52 \%$ TASK-1/TASK-3 heterodimers, $34 \%$ TASK-3, and $14 \%$ TASK-1 channels. These observations suggest that the appropriate expression of particular TASK channel subunit combinations is subject to a high level of regulation. Indeed, this point is further exemplified by the upregulation of TASK channels we consistently observe in response to the removal of a tonic $\mathrm{GABA}_{\mathrm{A}}$ receptormediated conductance in CGNs (Fig. $3 B$ ) (Brickley et al., 2001). Thus, novel mechanisms must exist to regulate the availability of specific $\mathrm{K}_{2 \mathrm{P}}$ channels. For example, covalent modification of TWIK-1 by sumoylation switches off channel activity, suggesting that specific $\mathrm{K}_{2 \mathrm{P}}$ channels may be active only under certain physiological conditions (Rajan et al., 2005).

What underlies the increased contribution from TASK-3 channels?

The in situ hybridization and quantitative PCR experiments indicated that none of the $\mathrm{K}_{2 \mathrm{P}}$ subunits examined are upregulated, and so this phenomenon does not explain the normalization of $I_{\mathrm{K}(\mathrm{SO})}$ that is apparent in the TASK-1 KO strain. A simple explanation for the normalized $I_{\mathrm{K}(\mathrm{SO})}$ in the TASK-1 KO is related to differences in the single-channel properties of the various TASK channels. TASK-1 homodimeric channels have a low single-channel conductance (16 pS) compared with TASK-3 channels (36 pS) (Han et al., 2002). Also, the open time distribution for TASK-1 channels is briefer (fitted by a single exponential with a time constant of $0.7 \mathrm{~ms}$ at $-60 \mathrm{mV}$ ) than that observed for TASK-3 channels (time constant of $1.7 \mathrm{~ms}$ ) (Han et al., 2002). The single-channel currents arising from TASK-1/TASK-3 heterodimeric channels have the same kinetic and conductance properties as TASK-3 homodimeric channels but have an intermediate sensitivity to changes in $\mathrm{pH}$ (Kang et al., 2004). Consistent with these observations from recombinant expression studies, CGNs in culture exhibit channel opening equivalent to TASK-1 and TASK-3 homodimeric and TASK1/TASK-3 heterodimeric channel types (Kang et al., 2004). Therefore, because of their relatively high open probability at physiological pH, TASK-3 homodimers will contribute more charge to $I_{\mathrm{K}(\mathrm{SO})}$ than an equivalent number of TASK-1 homodimeric or TASK-1/TASK-3 heterodimeric $\mathrm{K}_{2 \mathrm{P}}$ channels.

The physiological significance of TASK channel subunit composition for proton and $\mathrm{Zn}^{2+}$ modulation

Regulation of the input conductance of a neuron by modulating a conductance such as $I_{\mathrm{K}(\mathrm{SO})}$ will impact on the integration of 
afferent input not only by hyperpolarizing the membrane but also by altering the amplitude and duration of incoming EPSP/ IPSPs. In CGNs, the input conductance is primarily determined by $I_{\mathrm{K}(\mathrm{SO})}$, but a tonic $\mathrm{GABA}_{\mathrm{A}}$ receptor-mediated conductance also contributes to its resting excitability (Brickley et al., 1996, 2001; Hamann et al., 2002). Therefore, changing the properties of $I_{\mathrm{K}(\mathrm{SO})}$ in the manner described here may have consequences for cerebellar function in a manner only previously explored for $\mathrm{GABA}_{\mathrm{A}}$ receptor-mediated tonic inhibition (Mitchell and Silver, 2003). Indeed, the impaired motor coordination of TASK-1 KO mice, evidenced by poor performance on the accelerating rotarod and in traversing an uplifted narrow horizontal beam, may indicate a cerebellar deficit (Hirai et al., 2003). However, this would represent a rather subtle alteration in cerebellar function because there is no evidence of the gait abnormalities, tremor, or ataxia so often associated with cerebellar defects (Aiba et al., 1994; Watanabe et al., 1998; Hashimoto et al., 1999). Other brain regions involved in these types of integrative motor tasks, such as the thalamus, basal ganglia, and motor cortex, are known to express low levels of TASK-1. High levels of TASK-1 gene expression are found in dorsal raphe cells and motor neurons, as well as in heart and adrenal glands (Duprat et al., 1997; Kim et al., 1998; Czirjak et al., 2000; Bayliss et al., 2003). Therefore, a firmer conclusion concerning the role of TASK-1 channels in cerebellar function may require the selective removal of TASK-1 gene expression from adult CGNs (Aller et al., 2003).

In agreement with previous data (Duprat et al., 1997; Talley et al., 2000; Brickley et al., 2001; Mulkey et al., 2004), we demonstrate that a native TASK-mediated leak conductance will be modulated by alterations in extracellular $\mathrm{H}^{+}$concentration. We further show that TASK-1-containing channels preferentially assemble as $\mathrm{Zn}^{2+}$-insensitive TASK-1/TASK-3 heterodimers in adult CGNs (different to the situation reported for neonatal granule cells). Although there are many brain areas in which the levels of TASK- 3 mRNA are considerably greater than those encoding TASK-1 (for rat, see Karschin et al., 2001; Talley et al., 2001), it remains to be seen whether homodimeric TASK-3 channels are present in any adult brain region. Studies using other $\mathrm{K}_{2 \mathrm{P}}$ channel KO mouse lines (especially TASK-3) will help elucidate further the functional significance of controlling the input conductance of a neuron via the action of endogenous $\mathrm{Zn}^{2+}$ on TASK channels.

\section{References}

Aiba A, Kano M, Chen C, Stanton ME, Fox GD, Herrup K, Zwingman TA, Tonegawa S (1994) Deficient cerebellar long-term depression and impaired motor learning in mGluR1 mutant mice. Cell 79:377-388.

Aller MI, Jones A, Merlo D, Paterlini M, Meyer AH, Amtmann U, Brickley S, Jolin HE, McKenzie ANJ, Monyer H, Farrant M, Wisden W (2003) Cerebellar granule cell Cre recombinase expression. Genesis 36:97-103.

Bayliss DA, Sirois JE, Talley EM (2003) The TASK family: two-pore domain background $\mathrm{K}^{+}$channels. Mol Interv 3:205-219.

Berg AP, Talley EM, Manger JP, Bayliss DA (2004) Motoneurons express heteromeric TWIK-related acid-sensitive $\mathrm{K}^{+}$(TASK) channels containing TASK-1 (KCNK3) and TASK-3 (KCNK9) subunits. J Neurosci 24:6693-6702.

Brickley SG, Cull-Candy SG, Farrant M (1996) Development of a tonic form of synaptic inhibition in rat cerebellar granule cells resulting from persistent activation of GABAA receptors. J Physiol (Lond) 497:753-759.

Brickley SG, Revilla V, Cull-Candy SG, Wisden W, Farrant M (2001) Adaptive regulation of neuronal excitability by a voltage-independent potassium conductance. Nature 409:88-92.

Clarke CE, Veale EL, Green PJ, Meadows HJ, Mathie A (2004) Selective block of the human 2-P domain potassium channel, TASK-3, and the native leak potassium current, IKSO, by zinc. J Physiol (Lond) 560:51-62.

Cotton JF, Liao Zou H, Liu C, Au JD, Yost SC (2004) Identification of native rat cerebellar granule cell currents due to background K channel KCNK5 (TASK-2). Mol Brain Res 128:112-120.

Czirjak G, Enyedi P (2002) Formation of functional heterodimers between the TASK-1 and TASK-3 two-pore domain potassium channel subunits. J Biol Chem 277:5426-5432.

Czirjak G, Enyedi P (2003) Ruthenium red inhibits TASK-3 potassium channel by interconnecting glutamate 70 of the two subunits. Mol Pharmacol 63:646-652.

Czirjak G, Fischer T, Spat A, Lesage F, Enyedi P (2000) TASK (TWIKrelated acid-sensitive $\mathrm{K}^{+}$channel) is expressed in glomerulosa cells of rat adrenal cortex and inhibited by angiotensin II. Mol Endocrinol 14:863-874.

Czirjak G, Toth ZE, Enyedi P (2004) The two-pore domain $\mathrm{K}^{+}$channel, TRESK, is activated by the cytoplasmic calcium signal through calcineurin. J Biol Chem 279:18550-18558.

Duprat F, Lesage F, Fink M, Reyes R, Heurteaux C, Lazdunski M (1997) TASK, a human background $\mathrm{K}^{+}$channel to sense external $\mathrm{pH}$ variations near physiological pH. EMBO J 16:5464-5471.

Gabriel A, Abdallah M, Yost CS, Winegar BD, Kindler CH (2002) Localization of the tandem pore domain $\mathrm{K}^{+}$channel KCNK5 (TASK-2) in the rat central nervous system. Brain Res Mol Brain Res 98:153-163.

Goldstein SA, Bockenhauer D, O'Kelly I, Zilberberg N (2001) Potassium leak channels and the KCNK family of two-P-domain subunits. Nat Rev Neurosci 2:175-184.

Gu W, Schlichthorl G, Hirsch JR, Engels H, Karschin C, Karschin A, Derst C, Steinlein OK, Daut J (2002) Expression pattern and functional characteristics of two novel splice variants of the two-pore-domain potassium channel TREK-2. J Physiol (Lond) 539:657-668.

Gutman GA, Chandy KG, Adelman JP, Aiyar J, Bayliss DA, Clapham DE, Covarriubias M, Desir GV, Furuichi K, Ganetzky B, Garcia ML, Grissmer S, Jan LY, Karschin A, Kim D, Kuperschmidt S, Kurachi Y, Lazdunski M, Lesage F, Lester HA, et al. (2003) International Union of Pharmacology. XLI. Compendium of voltage-gated ion channels: potassium channels. Pharmacol Rev 55:583-586.

Hamann M, Rossi DJ, Attwell D (2002) Tonic and spillover inhibition of granule cells control information flow through cerebellar cortex. Neuron 33:625-633.

Han J, Truell J, Gnatenco C, Kim D (2002) Characterization of four types of background potassium channels in rat cerebellar granule neurons. J Physiol (Lond) 542:431-444.

Hashimoto K, Fukaya M, Qiao X, Sakimura K, Watanabe M, Kano M (1999) Impairment of AMPA receptor function in cerebellar granule cells of ataxic mutant mouse stargazer. J Neurosci 19:6027-6036.

Heurteaux C, Guy N, Laigle C, Blondeau N, Duprat F, Mazzuca M, LangLazdunski L, Widmann C, Zanzouri M, Romey G, Lazdunski M (2004) TREK-1, a $\mathrm{K}^{+}$channel involved in neuroprotection and general anesthesia. EMBO J 23:2684-2695.

Hirai H, Launey T, Mikawa S, Torashima T, Yanagihara D, Kasaura T, Miyamoto A, Yuzaki M (2003) New role of delta2-glutamate receptors in AMPA receptor trafficking and cerebellar function. Nat Neurosci 6:869-876.

Jones A, Korpi ER, McKernan RM, Pelz R, Nusser Z, Makela R, Mellor JR, Pollard S, Bahn S, Stephenson FA, Randall AD, Sieghart W, Somogyi P, Smith AJ, Wisden W (1997) Ligand-gated ion channel subunit partnerships: $\mathrm{GABA}_{\mathrm{A}}$ receptor $\alpha 6$ subunit gene inactivation inhibits delta subunit expression. J Neurosci 17:1350-1362.

Jones BJ, Roberts DJ (1968) The effects of intracerebroventricularly administered noradnamine and other sympathomimetic amines upon leptazol convulsions in mice. Br J Pharmacol 34:27-31.

Kang D, Han J, Talley EM, Bayliss DA, Kim D (2004) Functional expression of TASK-1/TASK-3 heteromers in cerebellar granule cells. J Physiol (Lond) 554:64-77.

Karschin C, Wischmeyer E, Preisig-Muller R, Rajan S, Derst C, Grzeschik KH, Daut J, Karschin A (2001) Expression pattern in brain of TASK-1, TASK-3, and a tandem pore domain $\mathrm{K}^{+}$channel subunit, TASK-5, asso ciated with the central auditory nervous system. Mol Cell Neurosci 18:632-648.

Kim D, Fujita A, Horio Y, Kurachi Y (1998) Cloning and functional expression of a novel cardiac two-pore background $\mathrm{K}^{+}$channel (cTBAK-1). Circ Res 82:513-518.

Kim Y, Bang H, Kim D (2000) TASK-3, a new member of the tandem pore K1 channel family. J Biol Chem 275:9340-9347. 
Korpi ER, Koikkalainen P, Vekovischeva OY, Mäkelä R, Kleinz R, UusiOukari M, Wisden W (1998) Cerebellar granule-cell-specific GABAA receptors attenuate benzodiazepine-induced ataxia: evidence from alpha6-subunit-deficient mice. Eur J Neurosci 11:233-240.

Lauritzen I, Zanzouri M, Honore E, Duprat F, Ehrengruber MU, Lazdunski M, Patel AJ (2003) $\mathrm{K}^{+}$-dependent cerebellar granule neuron apoptosis. Role of task leak K ${ }^{+}$channels. J Biol Chem 278:32068-32076.

Leonoudakis D, Gray AT, Winegar BD, Kindler CH, Harada M, Taylor DM, Chavez RA, Forsayeth JR, Yost SC (1998) An open rectifier potassium channel with two pore domains in tandem cloned from rat cerebellum. J Neurosci 18:868-877.

Lesage F (2003) Pharmacology of neuronal background potassium channels. Neuropharmacology 44:1-7.

Lopes CM, Gallagher PG, Buck ME, Butler MH, Goldstein SA (2000) Proton block and voltage gating are potassium-dependent in the cardiac leak channel Kcnk3. J Biol Chem 275:16969-16978.

Maingret F, Patel AJ, Lazdunski M, Honore E (2001) The endocannabinoid anandamide is a direct and selective blocker of the background $\mathrm{K}^{+}$channel TASK-1. EMBO J 20:47-54.

Mann-Metzer P, Yarom Y (1999) Electrotonic coupling interacts with intrinsic properties to generate synchronized activity in cerebellar networks of inhibitory interneurons. J Neurosci 19:3298-3306.

Mathie A, Clarke CE, Ranatunga KM, Veale EL (2003) What are the roles of the many different types of potassium channel expressed in cerebellar granule cells? Cerebellum 2:11-25.

Meadows HJ, Randall AD (2001) Functional characterisation of human TASK-3, an acid-sensitive two-pore domain potassium channel. Neuropharmacology 40:551-559.

Medhurst AD, Rennie G, Chapman CG, Meadows H, Duckworth MD, Kelsell RE, Gloger II, Pangalos MN (2001) Distribution analysis of human two pore domain potassium channels in tissues of the central nervous system and periphery. Brain Res Mol Brain Res 86:101-114.

Millar JA, Barratt L, Southan AP, Page KM, Fyffe RE, Robertson B, Mathie A (2000) A functional role for the two-pore domain potassium channel TASK-1 in cerebellar granule neurons. Proc Natl Acad Sci USA 97:3614-3618.

Mitchell KJ, Pinson KI, Kelly OG, Brennan J, Zupicich J, Scherz P, Leighton PA, Goodrich LV, Lu X, Avery BJ, Tate P, Dill K, Pangilinan E, Wakenight P, Tessier-Lavigne M, Skarnes WC (2001) Functional analysis of secreted and transmembrane proteins critical to mouse development. Nat Genet 28:241-249.

Mitchell SJ, Silver RA (2003) Shunting inhibition modulates neuronal gain during synaptic excitation. Neuron 38:433-445.

Mulkey DK, Stornetta RL, Weston MC, Simmons JR, Parker A, Bayliss DA, Guyenet PG (2004) Respiratory control by ventral surface chemoreceptor neurons in rats. Nat Neurosci 7:1360-1369.
North RA (2000) Potassium-channel closure taken to TASK. Trends Neurosci 23:234-235.

Patel AJ, Honoré E (2001) Properties and modulation of mammalian 2P domain $\mathrm{K}^{+}$channels. Trends Neurosci 24:339-346.

Rajan S, Wischmeyer E, Xin Liu G, Preisig-Muller R, Daut J, Karschin A, Derst C (2000) TASK-3, a novel tandem pore domain acid-sensitive $\mathrm{K}^{+}$channel. An extracellular histiding as $\mathrm{pH}$ sensor. J Biol Chem 275:16650-16657.

Rajan S, Wischmeyer E, Karschin C, Preisig-Muller R, Grzeschik KH, Daut J, Karschin A, Derst C (2001) THIK-1 and THIK-2, a novel subfamily of tandem pore domain $\mathrm{K}^{+}$channels. J Biol Chem 276:7302-7311.

Rajan S, Plant LD, Rabin ML, Butler MH, Goldstein SAN (2005) Sumoylation silences the plasma membrane leak $\mathrm{K}^{+}$channel K2P1. Cell 121:37-47.

Takayasu Y, Iino M, Furuya N, Ozawa S (2003) Muscarine-induced increase in frequency of spontaneous EPSCs in Purkinje cells in the vestibulecerebellum of the rat. J Neurosci 23:6200-6208.

Talley EM, Lei Q, Sirois JE, Bayliss DA (2000) TASK-1, a two-pore domain $\mathrm{K}^{+}$channel, is modulated by multiple neurotransmitters in motoneurons. Neuron 25:399-410.

Talley EM, Solorzano G, Lei Q, Kim D, Bayliss DA (2001) CNS distribution of members of the two-pore-domain (Kcnk) potassium channel family. J Neurosci 21:7491-7505.

Vega-Saenz de Miera E, Lau DH, Zhadina M, Pountney D, Coetzee WA, Rudy B (2001) KT3.2 and KT3.3, two novel human two-pore $\mathrm{K}^{+}$channels closely related to TASK-1. J Neurophysiol 86:130-142.

Warth R, Barriere H, Meneton P, Bloch M, Thomas J, Tauc M, Heitzmann D, Romeo E, Verrey F, Mengual R, Guy N, Bendahhou S, Lesage F, Poujeol P, Barhanin J (2004) Proximal renal tubular acidosis in TASK2 $\mathrm{K}^{+}$ channel-deficient mice reveals a mechanism for stabilizing bicarbonate transport. Proc Natl Acad Sci USA 101:8215-8220.

Watanabe D, Inokawa H, Hashimoto K, Suzuki N, Kano M, Shigemoto R, Hirano T, Toyama K, Kaneko S, Yokoi M, Moriyoshi K, Suzuki M, Kobayashi K, Nagatsu T, Kreitman RJ, Pastan I, Nakanishi S (1998) Ablation of cerebellar Golgi cells disrupts synaptic integration involving GABA inhibition and NMDA receptor activation in motor coordination. Cell 95:17-27.

Watkins CS, Mathie A (1996) A non-inactivating $\mathrm{K}^{+}$current sensitive to muscarinic receptor activation in rat cultured cerebellar granule neurons. J Physiol (Lond) 491:401-412.

Wisden W, Morris BJ (1994) In situ hybridization with synthetic oligonucleotide probes. In: In situ hybridization protocols for the brain (Wisden W, Morris BJ, eds), pp 9-43. London: Academic.

Young LJ, Nilsen R, Waymire KG, MacGregor GR, Insel TR (1999) Increased affiliative response to vasopressin in mice expressing the V1a receptor from a monogamous vole. Nature 400:766-768. 